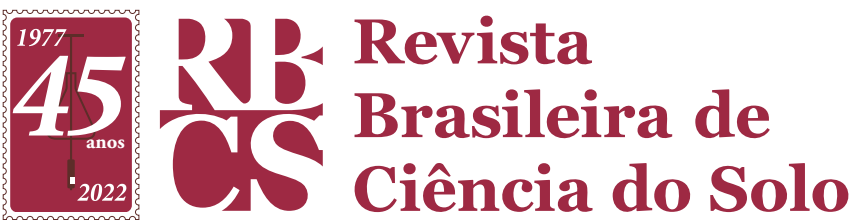

Division - Soil Use and Management | Commission - Soil and Water Management and Conservation

\title{
Adoption of the no-tillage system in Paraná State: A (re)view
}

\author{
Edivan José Possamai ${ }^{(1) *}$ (D), Paulo Cesar Conceição ${ }^{(2)}$ (D), Caroline Amadori ${ }^{(2)}$ (D), \\ Marie Luise Carolina Bartz ${ }^{(3)}$ (D), Ricardo Ralisch ${ }^{(4)}$ (D), Marcelo Vicensi ${ }^{(5)}$ (D) and \\ Ericson Fagundes Marx ${ }^{(6)}$ \\ ${ }^{(1)}$ Instituto de Desenvolvimento Rural do Paraná, Pato Branco, Paraná, Brasil. \\ (2) Universidade Tecnológica Federal do Paraná, Dois Vizinhos, Paraná, Brasil. \\ ${ }^{(3)}$ Centro de Ecologia Funcional, Departamento de Ciências da Vida, Universidade de Coimbra, Coimbra, \\ Portugal. \\ (4) Universidade Estadual de Londrina, Londrina, Paraná, Brasil \\ (5) Instituto de Desenvolvimento Rural do Paraná, Dois Vizinhos, Paraná, Brasil. \\ ${ }^{\left({ }^{6}\right)}$ Instituto de Desenvolvimento Rural do Paraná, Francisco Beltrão, Paraná, Brasil.
}

* Corresponding author:

E-mail: edivanjp@idr.pr.gov.br

Received: July 30, 2021

Approved: October 21, 2021

How to cite: Possamai EJ, Conceição PC, Amadori C, Bartz MLC, Ralisch R, Vicensi M, Marx EF. Adoption of the no-tillage system in Paraná State: A (re) view. Rev Bras Cienc Solo. 2022;46:e0210104.

https://doi.org/10.36783/18069657rbcs20210104

Editors: José Miguel Reichert (iD) and Gustavo Henrique Merten (1).

Copyright: This is an open-access article distributed under the terms of the Creative Commons Attribution License, which permits unrestricted use, distribution, and reproduction in any medium, provided that the original author and source are credited.
ABSTRACT: The concept of a no-tillage system (NTS), or "Sistema Plantio Direto," was established in Brazil from the evolution of no-tillage (NT) or "Plantio Direto," given the edaphoclimatic conditions and the need to promote chemical, physical and biological improvements in cultivated soils. While "Plantio Direto" is a conservationist practice, "Sistema Plantio Direto" presents itself as an agricultural production system based on the simultaneous adoption of minimum soil disturbance, maintenance of permanent soil cover and crop rotation. This study reviews the concepts of "Plantio Direto" and "Sistema Plantio Direto" in the Brazilian literature and uses two case studies in Paraná State to demonstrate the practical implications of these concepts. These two terms and their variations are recurrent themes in Brazilian scientific research and the professional environment, and may occur erroneously, hindering their adoption, results and implications. Regarding the "Sistema Plantio Direto," we highlight the need to clarify the concepts of its basic practices to parameterize and characterize this process. The definition of crop rotation, for example, requires limits on the number of species along a given time scale, thus enabling their identification. Regarding the case studies, most grain crops conducted in Paraná State did not adopt the "Sistema Plantio Direto," mainly neglecting the component of crop rotation. Nevertheless, the use of the "no-tillage system participatory quality index" (PQI) tool can contribute to the assessment and monitoring of the quality of the "Sistema Plantio Direto." However, it requires adjustments to differentiate the "Sistema Plantio Direto" from the "Plantio Direto."

Keywords: conservation agriculture, participatory quality index, soil management, crop rotation, no-tillage system. 


\section{INTRODUCTION}

Sustainable agricultural production is one of the greatest challenges of the 21st century because of the importance of agriculture, as demand for food and environmental preservation grows. The 2030 Agenda of the United Nations (UN) established goals for sustainable development in social, economic and environmental dimensions in this century. In particular, the goals for the agriculture sector were highlighted as: "zero hunger and sustainable agriculture," i.e., aiming to end hunger, achieve food security, improve nutrition and promote sustainable agriculture; and "terrestrial life," i.e., protect, recover and promote the sustainable use of terrestrial ecosystems, sustainably manage forests, fight desertification, halt and reverse land degradation, and halt the loss of biodiversity (United Nations Organization, 2016).

From the perspective that agriculture must reconcile production growth, poverty reduction and environmental preservation (OCDE and FAO, 2015), the adequate use of soil, as the basis of agricultural systems, is essential (Reichert et al., 2003). Conservation agriculture, understood as agriculture under the precepts of soil conservation science, using technologies that promote the preservation, maintenance, and/or recovery of natural resources through the integrated management of soil, water, and biodiversity, has an important role in this goal (Denardin et al., 2014; FAO, 2017).

Soil conservation for agriculture is based on the promotion of gains in agricultural production through the improvement of soil fertility without causing environmental damage, particularly with regards to soil and water management (Cassol et al., 2007). The no-tillage system (NTS) has proven to be able to reconcile these two viewpoints, namely, conservation and productivity, making it a reference in soil and water conservation management in agriculture in Brazil (Muzilli, 2006; Freitas and Landers, 2014) as well as globally (Bolliger et al., 2006; Derpsch et al., 2010).

In Brazil, the concept of NTS was established and consolidated over time, as an evolution of direct seeding without soil preparation, called no-tillage (NT), originating in England and the United States, adapted to Brazilian edaphoclimatic conditions (Cassol et al., 2007). Often adopted as synonyms, the NT and NTS are different concepts. Whereas NTS is an agricultural production system, composed of the basic principles of crop rotation, permanent soil cover and sowing without previous soil mobilization; NT is only considered as a sowing technique without previous soil preparation, or minimal soil disturbance, as proposed by Hernani and Salton (1998).

Thus, a relevant aspect in understanding NTS in Brazilian agriculture is the existence and use of different terminologies. "Plantio Direto," "Sistema Plantio direto," "Sistema de Plantio Direto," "Semeadura Direta," "Sistema Semeadura direta," "Sistema de Semeadura Direta," "Sistema de Plantio Direto na Palha," "Plantio na Palha," "Semeadura na Palha," "Sistema Plantio Direto na Palha," and "Semeadura Direta na Palha" are terms found in the Brazilian bibliography (Aratani, 2020). The lack of clarity regarding the use of these terminologies and their proper conceptualization, including in scientific studies, has resulted in the use of a given term for different practices or the use of several terms for the same practice, making it difficult to understand their results and impacts (Derpsch et al., 2014) within the scope of research, teaching, extension and public policies.

In 2022, the 50th anniversary of the first commercial annual crop sown without previous soil mobilization in Brazil will be completed. Located in Paraná State, it belongs to Herbert Bartz, a visionary farmer concerned about the environmental impacts of soil management adopted at that time (Freitas and Landers, 2014; Santin, 2018), whose state has become a reference in technology that revolutionized tropical and subtropical agriculture (Motter et al., 2015). However, in recent years, the partial adoption of NTS principles has been observed in grain crops in Paraná State (Telles et al., 2019) and Brazil (Fuentes-Llanillo et al., 2021a), characterizing it only as NT, and consequently, compromising the soil quality, which concerns different segments of society. 
This review aims to analyze the conceptual differences between the NTS and NT, based on the Brazilian literature, as well as to present two case studies on the practical implications of using these concepts in the evaluation and advances of the NTS in Paraná State. In this study, the terms NTS and NT in the English language are used as a translation for the discussion on the "Sistema Plantio Direto" and "Plantio Direto" adopted in Brazil, which are commonly adopted by scientists, technicians and farmers.

\section{NO-TILLAGE AND NO-TILLAGE SYSTEM}

Originating in England and the United States of America, direct seeding without soil disturbance, called NT in Brazil (Cassol et al., 2007), was introduced in the late 1960s in the Rio Grande do Sul State and in Paraná State, to reduce soil erosion resulting from intense soil mobilization in croplands (Derpsch et al., 1986; Cassol et al., 2007; Casão et al., 2012; Telles et al., 2013; Bertol et al., 2014; Fuentes-Llanillo et al., 2021a) as a soil conservation practice (Cassol et al., 2007). With its expansion in the 1980s, under Brazilian climate conditions, the characteristics of NT began to expand, with a set of additional technologies necessary to promote soil conservation and quality (Denardin et al., 2014; Fuentes-Llanillo et al., 2021a), from which the terminology "NTS" emerged, whose basic principles were minimum soil disturbance, permanent soil cover and diversification of crop species (Muzilli, 2006; Cassol et al., 2007; Denardin et al., 2014; Febrapdp, 2021; Fuentes-Llanillo et al., 2021a).

System is defined as a set of elements that interact with each other, which differs from a simple analysis of its parts (Bertalanffy, 2010). From a system perspective, the NTS came to be understood as an agricultural production system, arising from three fundamental practices (Cassol et al., 2007), with improvements in soil quality only occurring when these practices were integrated.

Over time, NTS had several beneficial effects on Brazilian agriculture. Initially, the effect observed was the reduction of soil erosion and the resulting environmental problems (Derpsch et al., 1986), followed by an increased grain yield (Debiasi et al., 2013) and the subsequent improvement in soil properties (Calegari et al., 1992). Long-term studies in different Brazilian regions, climates and soils have shown that the continuous use of NTS can improve the chemical (Sá et al., 2009; Rheinheimer et al., 2019), physical (Moraes et al., 2016; Reichert et al., 2016; Pires et al., 2017) and biological soil properties (Balota et al., 2014; Demetrio et al., 2020), and increase the soil organic matter (SOM) stock (Ferreira et al., 2018; Veloso et al., 2020), with its corresponding social and environmental advantages (Freitas and Landers, 2014).

From an environmental perspective, the NTS reduces the siltation of water bodies, the eutrophication of surface waters and the transportation of agrochemicals as well as improving the replenishment of groundwater and aquifers (Itaipu Binacional and Febrapdp, 2011), and sequestering atmospheric carbon via increased SOM (Cassol et al., 2007; Carvalho et al., 2009).

Although used synonymously in many cases, the concepts of NT and NTS are different. While NT is considered a soil conservation technique with seeding occurring directly on the residues of the previous crop and without soil preparation, the NTS comprises a set of technologies that promote soil conservation and increased productivity (Hernani and Salton, 1998). The NTS is a genuine Brazilian terminology resulting from the need to promote soil conservation and quality (Denardin et al., 2014). Internationally, the term "conservation agriculture" (CA) is adopted with similarity to the term NTS adopted in Brazil (FAO, 2017), with crop rotation as one of its distinctive characteristics (Kassam et al., 2019). In Brazil, however, the term CA is seen as a set of conservationist practices for soil, water, and biodiversity, used systemically in agriculture, including, for example, the 
integrated management of pests, diseases and weeds (Cassol et al., 2007). This adds another layer of conceptual difficulty to the understanding of the terms in use in this field.

The use of the terms "Plantio Direto" and "Sistema Plantio Direto" in Brazil, on the contrary, are considered inappropriate, as they refer to the action of depositing seeds and not plants in the soil, where "seeding" would be the correct term, in the same way as the term "system" is used in a generalized way without representing the fullness of the technology (Souza et al., 2019). Denardin et al. (2012) emphasized that the term "Plantio Direto" originates from an inadequate translation of the original English language (NT, no-till and zero tillage). Thus, the use of the term "Plantio Direto" must be taken from the meaning of its concept, with values beyond its etymological significance. As a result, "Plantio Direto" and "Semeadura Direta" are used interchangeably, referring to the act of sowing without previously preparing the soil (Denardin et al., 2014).

Several terminologies have been used in Brazil over the years to represent sowing without soil preparation and its variations (Cassol et al., 2007). In exploratory studies in different Brazilian bibliographic databases analyzing the use of the terms, Aratani (2020) found the presence of 12 different variations, with a greater recurrence of the use of "Plantio Direto" and "Semeadura Direta." The use of the term "system" was also recurrent, but with less intensity in more rigorous scientific publications.

Analyzing the use of the terms "Plantio Direto," "Semeadura Direta," and its variations in scientific publications available online on the portal Scientific Electronic Library Online (SciELO, 2021) in several Brazilian journals in Portuguese (Table 1), 2,182 results were found, with a predominance of the terminology "Plantio Direto" and its variations in $77.6 \%$ of cases, and "Semeadura Direta" and its variations represented $22.4 \%$ of cases. Among all the variations, the use of "Plantio Direto" and "Sistema Plantio Direto" stood out, with 34.6 and $27.7 \%$ of cases, respectively, with the prefix "system" being used primarily when using the term "Plantio Direto" was used.

With respect to the terms used in the Revista Brasileira de Ciência do Solo (RBCS) (Brazilian Journal of Soil Science) (Table 1), the highest adoption was observed for the term "Plantio Direto" compared to "Semeadura Direta," with 75.6 and 24.4 \%, respectively, in Portuguese. When analyzing the variations of the terms, "Sistema Plantio Direto" and "Plantio Direto" were the most frequent, at 36 and $32 \%$, respectively. It is worth noting that after the RBCS became an exclusively English-language journal in 2016, the most commonly employed terminologies became "no-tillage" (48.3\%), "no-tillage system" $(26.4 \%)$, "no-till" ( $24.1 \%)$, and "conservation agriculture," with only one citation ( $1.2 \%$ ), demonstrating the predominance of the term "no-tillage system" as a reference to the term "Sistema Plantio Direto" in Brazilian journals.

The terms "Sistema de Plantio Direto," "Plantio Direto na Palha," "Sistema Semeadura Direta," and "Sistema de Semeadura Direta" were also observed in both analyzed segments, albeit at a lower frequency. Notably, the use of the terms "Plantio Direto" and "Sistema Plantio Direto" are predominant in Brazilian scientific publications, demonstrating that, despite not being the most appropriate from an etymological point of view (Souza et al., 2019), they have a popularized use. Therefore, their strict definition based on key concepts (Denardin et al., 2012) is of fundamental importance. However, when consulting the literature, experiments conducted without crop rotation and in short periods are often referred to as NTS studies (Ceretta et al., 2002; Carvalho et al., 2008; Guareschi et al., 2014), contradicting the concept of NTS.

In 2017, Brazil had 33 million hectares under NT, corresponding to $61 \%$ of the area under annual crops, according to Fuentes-Llanillo et al. (2021b). However, the same quantity or the same NT area from previous surveys are cited in scientific publications and free consultation sites (Passos et al., 2018; Scheid et al., 2018), such as the Brazilian NTS area, which shows the nonsense practical use of the terminology. 
Table 1. Number and percentage of use of the terms "Plantio Direto," "Semeadura Direta," and variations in scientific publications available online in Brazilian journals, and specifically in the Revista Brasileira de Ciência do Solo (RBCS) (Brazilian Journal of Soil Science) from the Scientific Electronic Library Online - Brazil (SciELO-Brasil)

\begin{tabular}{|c|c|c|c|c|}
\hline \multirow{2}{*}{ Terminology } & \multicolumn{2}{|c|}{ General $^{(1)}$} & \multicolumn{2}{|c|}{$\mathrm{RBCS}^{(2)}$} \\
\hline & Publications & $\%$ & Publications & $\%$ \\
\hline & \multicolumn{4}{|c|}{ Portuguese } \\
\hline Plantio direto & 1694 & 77.6 & 437 & 75.6 \\
\hline Plantio direto & 756 & 34.6 & 185 & 32.0 \\
\hline Sistema plantio direto & 604 & 27.7 & 208 & 36.0 \\
\hline Sistema de plantio direto & 311 & 14.3 & 40 & 6.9 \\
\hline Plantio direto na palha & 17 & 0.8 & 3 & 0.5 \\
\hline Sistema de plantio direto na palha & 6 & 0.3 & 1 & 0.2 \\
\hline Semeadura direta & 488 & 22.4 & 141 & 24.4 \\
\hline Semeadura direta & 336 & 15.4 & 92 & 15.9 \\
\hline Sistema semeadura direta & 14 & 0.6 & 7 & 1.2 \\
\hline Sistema de semeadura direta & 138 & 6.3 & 42 & 7.3 \\
\hline \multirow[t]{2}{*}{ Total (Portuguese) } & 2182 & 100 & 578 & 100 \\
\hline & \multicolumn{4}{|c|}{ English } \\
\hline No-tillage & - & - & 65 & 74.7 \\
\hline No-tillage & - & - & 42 & 48.3 \\
\hline No-tillage system & - & - & 23 & 26.4 \\
\hline No-till & - & - & 21 & 24.1 \\
\hline Conservation agriculture & - & - & 1 & 1.2 \\
\hline Total (English) & - & - & 66 & 100 \\
\hline
\end{tabular}

(1) Search in Brazilian journals, without period restriction. ${ }^{(2)}$ Search with terms in Portuguese from 1997 to 2015, and search with terms in English in subsequent years. Source: (SciELO, 2021)

Considering the area under NT in Brazil, it is estimated that between $10 \%$ (Martins et al., 2018) and $20 \%$ (Denardin, 2018) make effective use of the set of NTS principles. The non-adoption of the NTS, but the adoption of only the NT, may decrease soil quality (Fuentes-Llanillo et al., 2021a), including compaction and low water infiltration, soil erosion in rainy periods and water deficit in dry periods (Denardin, 2018). However, the conceptualization of NTS is intrinsically composed of an understanding and adoption of the three conservation practices that constitute its pillars. This requires an understanding of the concept of these practices to characterize the concept of NTS better.

\section{Minimum soil mobilization}

Direct seeding or "Plantio Direto" is a soil conservation practice where sowing takes place without previous soil preparation, where soil mobilization is restricted to the seed deposition site, performed directly on the remains of the previous crop (Bertoni and Lombardi Neto, 2014; Maria et al., 2019).

Considering that the average spacing between rows for sowing summer crops (corn, beans or soybean) is $0.50 \mathrm{~m}$ and the use of a system type furrower with seed and fertilizer deposition occurs at a depth up to $0.10 \mathrm{~m}$, the soil volume tilled does not exceed $5 \%$ of the tilled area, compared to plowing in conventional tillage (CT). However, in CT, in addition to plowing, harrowing (one or two times) is necessary before the seeding of commercial crops.

Therefore, the no-disturbance soil in the NT, in contrast to $\mathrm{CT}$, provides a new dynamic in terms of its physical, chemical and biological properties, no longer requiring 
periodic revolving and homogenization, resulting in the formation of attribute gradients along with the profile, whether chemical, physical, or biological. Studies have shown that grain yield in NT has an initial phase in which the production can be less than or equal to the system with tillage, known as the soil stabilization phase (Franchini et al., 2012; Debiasi et al., 2013), which is variable as a function of time, place and crop cultivation.

Comparing systems with and without tillage, under the succession of soybean and wheat, Debiasi et al. (2013) observed that this stabilization period lasted 12 years, analyzed by the accumulation of SOM and its effects on chemical properties (increase in CEC, increase in $\mathrm{P}$, and reduction in Al phytotoxicity), physical (greater aggregation and higher water retention) and biological (nitrogen biological fixation, diversification of living organisms and their activity). Franchini et al. (2012) defined a period of six years for the stabilization of crop productivity when production systems with crop rotation were adopted, and 12 years when crop succession prevailed. Pereira Neto et al. (2007) evaluated the development of the soil structure and concluded that the NT stabilization phase was surpassed after nine years, where the areas under NTS had structures similar to those of native vegetation. Sá et al. (2019a) mentioned that the NTS was consolidated after ten years of implementation, with the consequences of stabilizing density, accumulation of straw under the surface, increased levels of carbon, phosphorus, CEC, water storage and cycling of nutrients, and a reduction of nitrogen demand due to the increase in its mineralization via straw.

In summary, after the adoption of the minimum soil disturbance, a time of stabilization is required for the consolidation of the new system. Only after this period, ranging from 6 to 12 years, can it be considered an NTS that is dependent on the crop cultivation practiced and of the place.

\section{Soil cover}

The soil cover is among vegetative soil conservation practices, considered living or dead cover (straw), in which the accumulated phytomass from previous crops acts as protection to the energy of the impact of raindrops on the soil surface, and to the shear energy of the runoff, is an important practice for erosion control (Heckler et al., 1998; Bertoni and Lombardi Neto, 2014; Maria et al., 2019). Furthermore, it influences soil temperature, evaporation, water infiltration and storage, and SOM accumulation (Heckler et al., 1998; Maria et al., 2019). It depends on the quantity and quality of aboveground phytomass added to the system, as well as the speed of its decomposition, which varies depending on the climate, microbiota and composition of the material, ensuring total soil coverage (Canalli et al., 2019). As a result, the maintenance of the permanent soil cover influences the dynamics of the SOM. However, as pointed out by Cassol et al. (2007), while soil cover is essential for reducing erosion caused by the kinetic energy of raindrops, it does not reduce the kinetic energy of runoff at the same intensity, requiring the adoption of complementary conservation practices of erosion control, such as terracing and level cultivation.

Heckler et al. (1998) reported that an average of $5 \mathrm{Mg} \mathrm{ha}^{-1}$ dry matter should be maintained on the soil surface over time to ensure a minimum coverage of $80 \%$ of the surface in the NTS. However, the loss of soil and water is directly proportional to the percentage of soil cover, where a soil cover of $100 \%$ is desirable (Maria et al., 2019).

Regarding the amount of phytomass needed to maintain or increase SOM, Canalli et al. (2019) cite annual dry matter input needs, ranging from 6 to $7 \mathrm{Mg} \mathrm{ha}^{-1} \mathrm{yr}^{-1}$ for the subtropical high altitude climate, 7.5 to $8.0 \mathrm{Mg} \mathrm{ha}^{-1} \mathrm{yr}^{-1}$ for the subtropical low altitude climate and transition between subtropical and tropical climates, and 10 to $12 \mathrm{Mg} \mathrm{ha}^{-1} \mathrm{yr}^{-1}$ for tropical climates. 
Thus, permanent soil coverage for the NTS is obtained by the contribution of phytomass in sufficient quantity to allow for a coverage of $100 \%$ of the surface. This quantity must persist over time; its distribution throughout the year and its quality are important for this, where materials with a high carbon to nitrogen ratio are desirable because of their slower decomposition, such as grasses, which stand out in the process of maintaining soil cover, due to higher phytomass production, covering the soil for a longer period (Heckler et al., 1998; Canalli et al., 2019).

\section{Crop rotation}

Crop rotation was the last principle to be included in the characterization of NTS, as minimal soil mobilization and permanent soil cover have a direct relationship with the initial purpose of NT, reducing the erosion processes. However, crop rotation has become the principle of promoting soil quality in the NTS, improving chemical, physical and biological fertility (Santos and Reis, 2001; Franchini et al., 2011a), in addition to the simple reduction of erosive processes, promoted by the other two principles.

Despite being a soil conservation practice (Bertoni and Lombardi Neto, 2014; Conceição, 2019; Maria et al., 2019; Souza et al., 2019), initially, the rotation of species within NT was recommended as a practice for the biological and cultural control of pests, diseases and weeds (Santos and Reis, 2001; Calegari, 2006; Muzilli, 2006), because of the conditions required for the survival of pests and diseases in the cultural remains of undisturbed soil.

Crop rotation proved to be important in soil management systems without soil disturbance over time. In addition to allowing for the management of pests, diseases and weeds (Bertoni and Lombardi Neto, 2014; Canalli and Bordin, 2019), this importance is because it allows for the exploration of different soil layers and nutrient cycling (Muzilli, 2006; Canalli et al., 2019) as well as the biological fixation of atmospheric $\mathrm{N}$ via leguminous species (Bertoni and Lombardi Neto, 2014; Canalli and Bordin, 2019), the maintenance of soil cover due to the use of species with higher phytomass production and higher $\mathrm{C} / \mathrm{N}$ ratio with the introduction of grasses (Canalli and Bordin, 2019; Canalli et al., 2019), and increased SOM and crop productivity (Medeiros et al., 1994; Bertoni and Lombardi Neto, 2014; Maria et al., 2019).

Despite the well-known importance of crop rotation as a conservation practice and as a principle of the NTS, its conceptual definition is not presented in an objective and clear way, particularly with regards to its variables. Generally, crop rotation is defined as the alternate and planned cultivation of different plant species with different botanical characteristics (nutritional requirements, dry matter production, shoot and root growth habits, $\mathrm{C} / \mathrm{N}$ ratio, biological fixation, and reaction to pests and diseases), whether commercial crops or cover crops, in the same plot over time (Medeiros and Calegari, 2006; Gonçalves et al., 2007; Bertoni and Lombardi Neto, 2014; Passos et al., 2018; Maria et al., 2019; Souza et al., 2019; Febrapdp, 2020a).

The concept of crop rotation has three variables: spatial, temporal and plant species. The spatial dimension is most precise among the variables, as it characterizes the analysis of a given location with a single management procedure over time (plot with homogeneous management). On the other hand, the temporal dimension presents variations in its conceptualization, including a lack of the repetition of the same species in an interval less than one to three years (Santos and Reis, 2001), alternation in a minimum period of three years (Canalli and Bordin, 2019), or alternation of species in the same season of the year (Franchini et al., 2011a). Conceptual models of crop rotations have been proposed (Medeiros and Calegari, 2006; Gonçalves et al., 2007), with a temporal variation ranging from three to seven years.

For variable plant species, the conceptualizations do not establish a quantitative or qualitative parameter for how many species are necessary to characterize a crop rotation, 
nor its relationship with the temporal variable. Exceptions include Calegari et al. (1998) and Franchini et al. (2011b), who established the alternation of species within the same season of the year, and Santos and Reis (2001), who established the non-repetition of a certain species within one to three years. Although a parameterization of plant species to characterize rotation is lacking, several crop rotation models have been proposed for use by farmers, such as Medeiros and Calegari (2006), Gonçalves et al. (2007), Franchini et al. (2011b), and Sá et al. (2019b) for Paraná State. Theoretically, these propositions are based on studies that mainly support the need to provide aboveground phytomass with the capacity to keep the soil covered and maintain or increase the levels of SOM, as well as manage diseases and pests.

In the proposal by Gonçalves et al. (2007), the authors considered two crops per agricultural year and a rotation period of three to seven harvests. It is worth noting that they proposed that soybeans, the main summer crop, should not be repeated over time, citing a maximum of $66 \%$ of the crops when the rotation predicts three crops, and a maximum of $75 \%$ of the crops when the rotation predicts four crops. The justification for including corn in the first crop is based on the fact that soybean contributes around $4 \mathrm{Mg} \mathrm{ha}^{-1}$ of dry matter, a value below the required annual contribution of quantities equal to or greater than $10 \mathrm{Mg} \mathrm{ha}^{-1}$ of dry matter (Canalli et al., 2019) and by gains in productivity in the cultivation of soybeans resulting from rotation (Franchini et al., 2011a).

However, proposals for crop rotations without alternating corn cultivation in the first crop have also been proposed by Medeiros and Calegari (2006) and Sá et al. (2019b). For example, they proposed crop rotations without alternating soybeans in the same growing season, but with the inclusion of grasses in single or intercropped crops, mainly corn with Urochloa in the crops of the second growing season of the agricultural year.

Although a clear definition of the concept of crop rotation is lacking, several points converge. In terms of the time scale, there is a need to consider a minimum period of three agricultural years and within these different growing seasons that can be up to three crops for the grain production systems. As for plant species, the following are convergent: (1) the need for arrangements that promote the annual contribution of sufficient dry matter to maintain soil cover and maintain or increase SOM content, especially with grasses because of the higher $\mathrm{C} / \mathrm{N}$ ratio; (2) not using the same species in sequential crops in the same agricultural year; (3) the alternation of different species and botanical families, within the same agricultural year and the same growing season over the various agricultural years, aiming at the management of pests, diseases, and weeds, the cycling of nutrients, and the diversification of species that promote higher quality.

One possibility for advancing the conceptualization of crop rotation, given the subjectivity of the variable "species," is the definition of a scale of intensity of species diversification (Rodale Institute, 2021), ranging from simple intensity (two or three species) to complex intensity (with 12 or more species), given that the increase in the number of species promotes higher quality systems (Conceição et al., 2005). However, at present, farmers commonly use consortia of cover crops, known as "blends," "cocktails," or "mixtures." In these cases, mixtures of cover crop seeds with two to twelve species are possible, creating an additional difficulty in using the intensity of species diversification as a parameter for crop rotation.

\section{CASE STUDIES}

Based on the premise that the reality of the field reflects the scientific reality in a more applied way and points out ways to understand the phenomena of the adoption of a given technology, we used two case studies to understand the dynamics of NT or NTS adoption in Paraná State. The first case study explores the data of cultivated areas with annual crops in the last 21 agricultural years, correlating with the NTS principles and 
its implications, while the second case study analyzes the soil management practices adopted by a group of farmers in southwestern Paraná within the conceptual definitions of NT and NTS established in this review. With these case studies, we propose a definition of the terminology that is consonant with the terminology adopted in the field.

\section{Case study 1: Evolution of the area of annual crops in Paraná State}

In the 2020/2021 harvest, Paraná had an area cultivated with grains of 6.12 million hectares, with the development of up to three crops in the same agricultural year, where the first crop occupied the total grain area, second crop with 2.68 million hectares, and third crop with 1.43 million hectares, considering only crops with commercial interest (Paraná, 2021).

The analysis of the area under grain crops in the last 21 agricultural years in Paraná State (Figure 1) shows that, in the first crop, also called the summer crop, there was a predominance of soybean cultivation, with an evolution of the occupied area, from $55 \%$ in the $2000 / 2001$ crop to $91 \%$ in 2020/2021. It is worth noting that from the 2009/2010 crop onwards, soybeans started to occupy more than $75 \%$ of the area, becoming over $90 \%$ in the last four years, with an annual increase of approximately 123.65 thousand hectares (Figure 2). Corn, the second largest crop in the first crop in the historical series of this area, decreased from $37 \%$ in 2000/2001 to $6 \%$ of the area occupied by 2020/2021, and since April 2014/2015 occupies less than $10 \%$ of the area, resulting in an annual decrease of 74.6 thousand hectares (Figure 2). Beans, the third crop in the occupied area, presented a small percentage variation within the historical series, ranging from $6 \%$ in $2000 / 2001$ to $2 \%$ in 2020/2021, but followed the same trend as corn, decreasing in the percentage of occupied area overall. Thus, there was an increase in the area occupied by soybeans in the first crop in Paraná State over the last 21 years, to the detriment of the percentage of the area cultivated with corn and beans, with soybean occupying $91 \%$ of the area of the first crop in the last four agricultural years.

An analysis of the same historical series for the second crop (Figure 1), also called "safrinha," indicated that there has been a constant predominance of corn cultivation over the years, occupying between $80 \%$ (2005/2006 crop) and $91 \%$ (2018/2018 crop) of the area, with an average of $90 \%$ of the area in the last five years. There has been an increase in the cultivated area of approximately 79.1 thousand hectares per year (Figure 2). Beans appear as the second main crop of this harvest, occupying an area of $9-10 \%$ in the last five years. Soybean is the third main crop in the second crop, with a variation of $1-2 \%$ in the last two years.

For the third crop, known as the winter crop, the historical series (Figure 1) demonstrates the predominance of wheat cultivation in Paraná State, occupying a constant area over the years, ranging from 69 to $83 \%$ of the area; in the last five years, it ranged from 75 to $80 \%$ of the occupation, but with an annual increase of approximately 2.6 thousand hectares (Figure 2). Black oat for grain production is the second main crop, with a variation in occupied area between 9 and $13 \%$ in the last five years. White oat and barley have had similar areas of occupation, between 4 and $6 \%$, in the last five years.

It is worth noting that this historical series does not include areas destined for the cultivation of cover crops and fallow areas, mainly in the second and third crops. Still, the third crops, such as wheat, comprised the second sequential commercial crop in the same agricultural year, after the cultivation of the first crop, given the days needed to complete the cycle.

Based on these data, in the last 21 years, there has been an intensification of grain monocultures in Paraná State, with soybean, corn, and wheat for the first, second, and third crops, respectively. Particularly in the last four to five agricultural years, there has been an intensification of annual successions "soybean+corn" in the Cfa climate region 
and "soybean+wheat" in the Cfb climate region (Franchini et al., 2011a), where the alternation soybean production has taken place in less than $10 \%$ of the area in the first crop, with corn no longer forming part of the rotations in the majority of the areas in the first crop. It is also worth noting that the "soybean+corn" succession over several crops does not promote soil quality due to the low soil cover promoted by second-crop corn straw (Franchini et al., 2011a) and increased soil compaction (Franchini et al., 2009), which leads to erosion problems.

Furthermore, it can be inferred from the data that only $9 \%$ of the areas occupied by annual crops in Paraná State made use of alternating species in the first crop in the last four agricultural years, within the NTS basic principle of adopting crop rotation. If crop rotation is to be used in the first crop, it should be inserted every ten crops. The

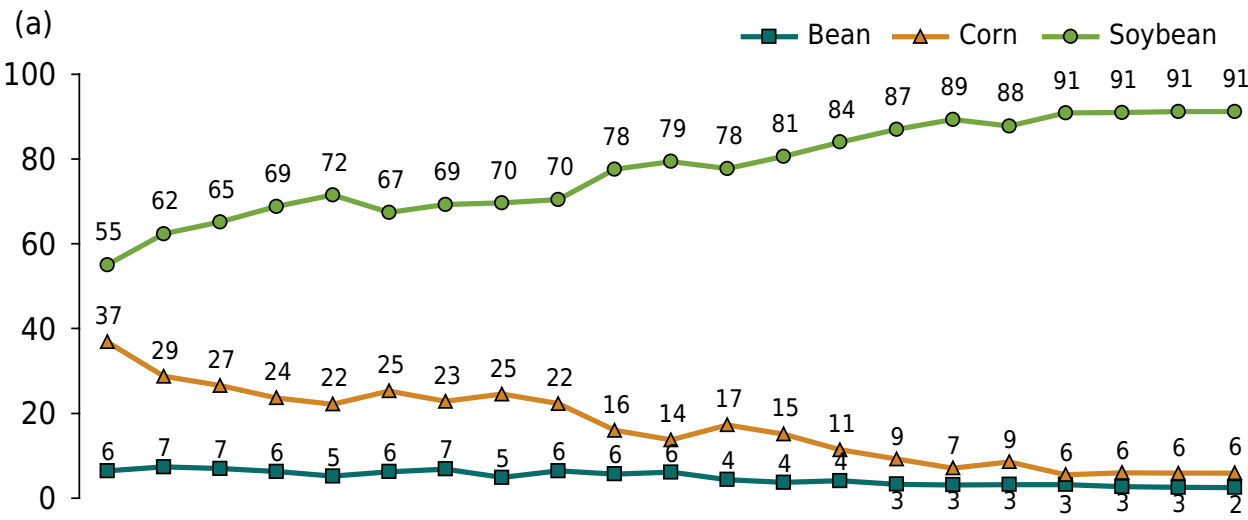

(b)

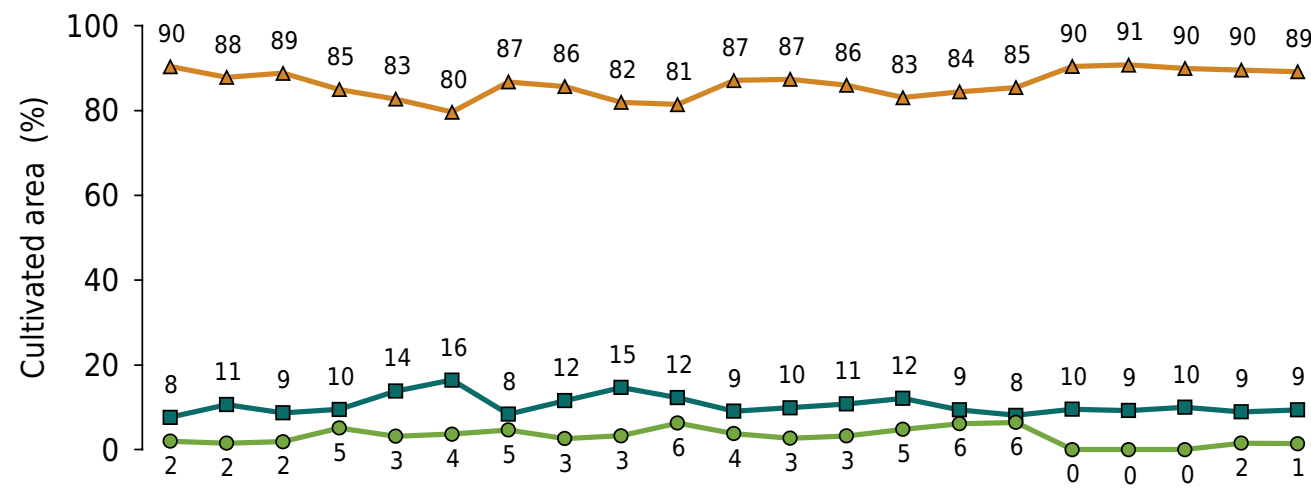

(c)

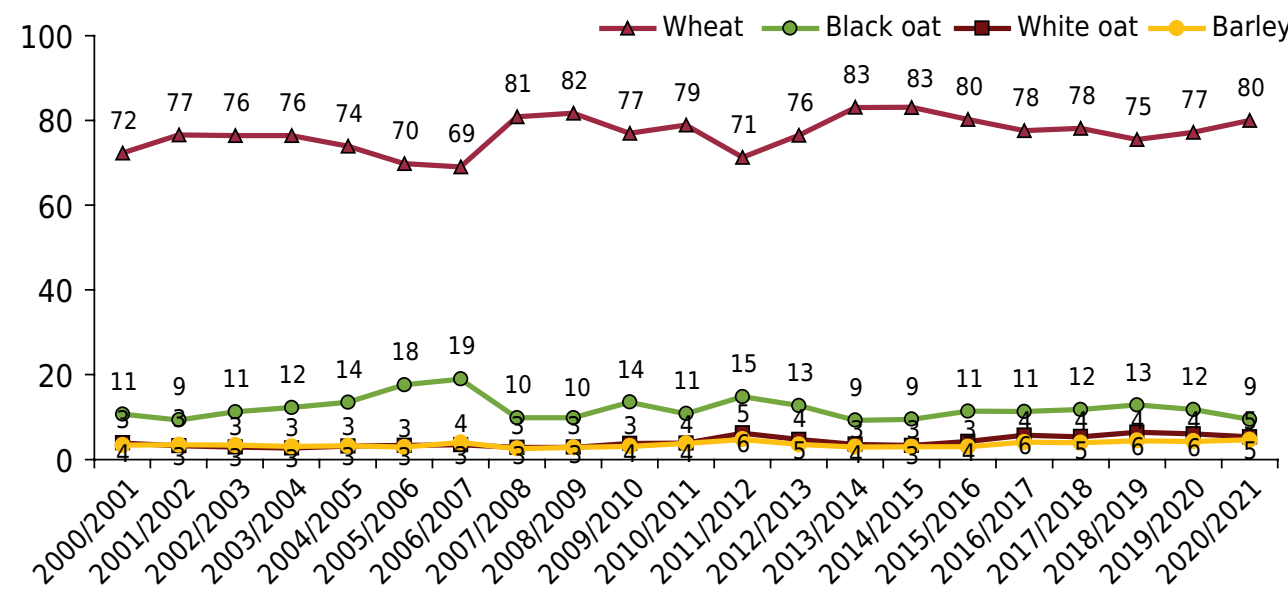

Harvest

Figure 1. Evolution of the percentage of the cultivated area with the main annual crops in Paraná State among agricultural years 2000/2001 and 2020/2021, referring to the first crop (a), second crop (b) and third crop (c). Source: Paraná (2021). 


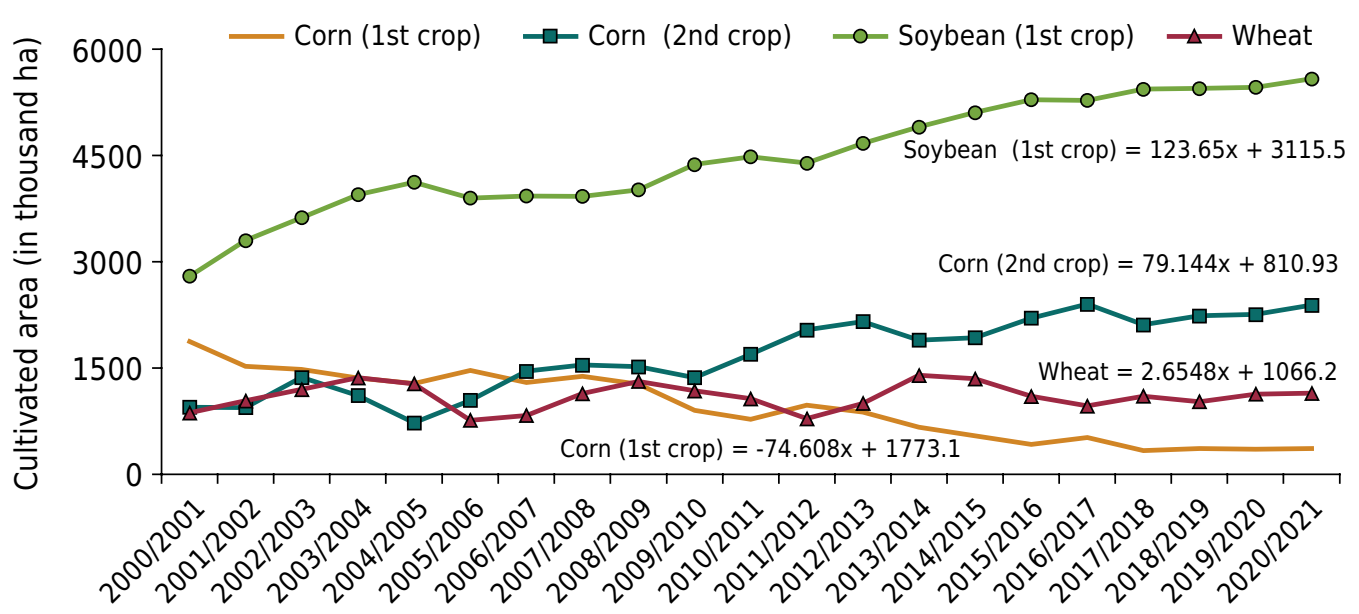

Harvest

Figure 2. Evolution of the cultivated area (in thousand hectares) with the main annual crops in Paraná State between agricultural years 2000/2001 and 2020/2021 in the different annual crops. Source: Paraná (2021).

cultivation of corn in the first crop allows for the input of quantities equal to or greater than $10 \mathrm{Mg} \mathrm{ha}^{-1}$ of dry matter, whereas soybean or corn from the second crop allows for input of approximately $4 \mathrm{Mg} \mathrm{ha}^{-1}$ of dry matter (Canalli et al., 2019). In the latter cases, this does not satisfy the needs for the input of straw into the system. The intercropping of second-crop corn with forage species, such as Urochloa spp., is important to improve the soil properties in the soybean/corn succession, as these increase phytomass production, improve soil cover, promote nutrient cycling and enhance the productivity of corn and soybeans compared to single corn (Alves et al., 2013; Ceccon et al., 2013). However, there is no statistical data on their adoption in Paraná.

An increase has been observed in the area under NT in Paraná State (Fuentes-Llanillo et al., 2021b); however, this was not accompanied by the adoption of one of the basic pillars of the NTS, which is crop rotation, as this can compromise the quality of the soil. Thus, it is not appropriate to use the total quantity of area under grains when citing areas of NTS adoption in the Paraná State, as most of these are NT because they do not adopt one of the basic pillars of the NTS, namely crop rotation.

\section{Case study 2: NTS participatory quality index}

Due to problems associated with NTS and quality, the "Federação Brasileira do Sistema Plantio Direto" (Febrapdp) and Itaipu Binacional initiated in Paraná Basin 3 (left bank of the Itaipu Reservoir lake) a methodology to assess the NTS quality, called the NTS participatory quality index (PQI), in 2009, which aimed to identify the advances and limitations of the NTS adopted by farmers with regards to soil and water conservation technologies (Itaipu Binacional and Febrapdp, 2011).

Participatory Quality Index is an integrated index that assesses the adoption of different conservation practices related to NTS quality, grouped into eight indicators. These indicators are crop rotation intensity (RI), crop rotation diversity (RD), persistence of straw (PS), soil tillage frequency (TF), correct terracing (CT), soil conservation evaluation (SC), balanced soil fertilization (BF), and adoption time (AT), for which ideal situations are known to promote soil quality over time (Itaipu Binacional and Febrapdp, 2011; Rollof et al., 2011a). It is worth noting that the three pillars of the NTS are included in the IQP by the RD, PS, and TF indicators for crop rotation, permanent soil cover, and minimum soil disturbance (Nunes et al., 2020a), but the methodology is not restricted only to these and evaluates a set of conservation practices. 
From a structured questionnaire that can be used by farmers, technicians, and extensionists, the information is transformed into quantitative indicators, assigning a score and classification for the NTS quality, as well as indicating the strengths, weaknesses and potential improvements to be made. For each indicator, a formula, ideal situation, critical level and weighting factor were established (Table 2). Adding to the weighted values, the $\mathrm{PQI}$ of the farm was included, ranging from zero to 10 , and classified into four quality categories: low (<4.5), regular (4.5-6.5), good (6.5-8.5) and very good (>8.5). The PQI proved to be an efficient methodology for determining the quality of NTS, correlating with the chemical and physical properties that are indicators of soil quality, especially with SOM (Rollof et al., 2011b; Nunes et al., 2020b), and is a promising tool for monitoring and managing the NTS.

With the aim of assessing NTS quality, identifying the limitations and advances in the adoption of the NTS in the southwest region of Paraná State, the PQI methodology was applied to 37 farms, assisted by extensionists from the IDR-Paraná (a technical assistance and rural extension agency in the Paraná State) through interviews with the application

Table 2. Indicators, input data, base value, calculation formula, critical situation, and weighting factors as components of the notillage system participatory quality index

\begin{tabular}{|c|c|c|c|c|c|}
\hline Indicators* & Input data & Base value & Formula & Critical situation & Weighting factors \\
\hline RI & $\begin{array}{l}\mathrm{NM}=\text { Number of months with living cover } \\
\text { in three years (except fallow and weeds) }\end{array}$ & 36 & $\mathrm{RI}=\mathrm{NM} / 36$ & 0.75 & 1.5 \\
\hline $\mathrm{RD}$ & $\begin{array}{c}\text { FD = Different families that occur during } \\
\text { the rotation in three years }\end{array}$ & 3 & $\mathrm{RD}=\mathrm{FD} / 3$ & 0.67 & 1.5 \\
\hline PS & $\begin{array}{l}\mathrm{GR}=\text { Number of grasses in a three-year } \\
\text { rotation (except grasses for hay or silage) }\end{array}$ & 6 & $P S=G R / 6$ & 0.5 & 1.5 \\
\hline TF & IEP = Interval between tillage (years) & 12 & $\mathrm{TF}=\mathrm{IEP} / 12$ & 0.5 & 1.5 \\
\hline CT & $\begin{array}{l}\text { ICT }=\text { Presence of terraces and frequency } \\
\text { of overflow in } 5 \text { years, the values are: } \\
\text { Without terrace }=0 \text {; With terrace and no } \\
\text { transfer, or } 1 \text { time in } 5 \text { years }=1 \text {; With } \\
\text { terrace and transshipment } 2 \text { or } 3 \text { times in } \\
5 \text { years }=0.5 \text {; With terrace and transfer } \\
\text { over } 3 \text { times in } 5 \text { years }=0 \text {. }\end{array}$ & 1 & $\mathrm{CT}=\mathrm{ICT} / 1$ & 0.5 & 1.0 \\
\hline \multirow{3}{*}{$\mathrm{SC}$} & $\begin{array}{c}\mathrm{ISCi}=\text { Leveled operations execution, } \\
\text { summing up the values: Performs seeding } \\
\text { at level: } 0.7 ; \text { Performs spraying at a } \\
\text { level: } 0.3 \text {. }\end{array}$ & 1 & \multirow{3}{*}{$\mathrm{SC}=\sum \mathrm{ISCi} / 4$} & \multirow{3}{*}{0.5} & \multirow{3}{*}{1.0} \\
\hline & $\begin{array}{l}\text { IC } \mathrm{C}=\text { Compacted soil, the values are: } \\
\text { Without compaction: } 2 \text {; Presence of } \\
\text { compaction only at headlands: } 1 \text {; Presence } \\
\text { of compaction in the entire crop: } 0 .\end{array}$ & 2 & & & \\
\hline & $\begin{array}{c}\mathrm{ICi}=\text { Absence of visible signs of erosion, } \\
\text { the values are: } \mathrm{Yes}=1 ; \text { No }=0 .\end{array}$ & 1 & & & \\
\hline BF & $\begin{array}{c}\mathrm{IBFi}=\text { Operations carried out based on } \\
\text { soil analysis results, when using organic } \\
\text { waste, the values are: Liming }=0.5 ; \\
\text { Chemical fertilization }=0.5 \text {; Organic } \\
\text { waste }=1 \text { or } 0.5 \text { when the soil analysis } \\
\text { result is not considered. } \\
\text { IBFi }=\text { Operations carried out based } \\
\text { on results of soil analysis, without the } \\
\text { use of organic waste, the values are: } \\
\text { Liming }=0.5 ; \text { Chemical fertilization }=0.5\end{array}$ & 1 & $\begin{array}{l}\mathrm{BF}=\sum \mathrm{IBFi} / 2 \\
\text { (with waste) } \\
\quad \text { or } \\
\mathrm{BF}=\sum \mathrm{IBFi} / 1 \\
\quad \text { (without } \\
\text { waste) }\end{array}$ & 0.5 & 1.0 \\
\hline AT & $\mathrm{T}=$ Adopted time in years & 25 & $\mathrm{FC}=\mathrm{T} / 25$ & 0.3 & 1.0 \\
\hline
\end{tabular}

RI: crop rotation intensity; RD: crop rotation diversity; PS: persistence of straw; TF: soil tillage frequency; CT: correct terracing; SC: soil conservation evaluation; BF: balanced soil fertilization; AT: adoption time. The ideal level established for all indicators was 1.0. Source: Itaipu Binacional and Febrapdp (2011) and Febrapdp (2020b). 
of the "PQI 2.0 diagnostic questionnaire," made available by Febrapdp (2020c), whose general characterization is shown in table 3 . The surveys were conducted between May and September 2019, and the agricultural years analyzed were 2016/2017, 2017/2018 and 2018/2019.

Southwest Paraná comprises 42 municipalities, with a territorial extension of $17,033,695 \mathrm{~km}^{2}$ (Ipardes, 2020), between latitudes $25^{\circ} 28^{\prime} \mathrm{S}$ and $26^{\circ} 36^{\prime} \mathrm{S}$ and longitudes $53^{\circ} 59^{\prime} \mathrm{W}$ and $51^{\circ} 30^{\prime} \mathrm{W}$. According to the Köppen classification system (Nitsche et al., 2019), the climate corresponding to this region was Cfa and Cfb. Agricultural activity is the economic base of this region, composed of the production of soybean, corn, beans, wheat, meat, eggs, milk, and wood, with $40 \%$ of the total area set aside for intensive agriculture, wherein $41 \%$ of the total area shows potential for soil degradation by erosion due to rugged relief (Ipardes, 2009) and high rainfall erosivity (Waltrick et al., 2015).

The results were tabulated using electronic spreadsheets provided by Febrapdp (Febrapdp, 2020d) to obtain the values of the eight indicators and the PQI, as well as the classification of NTS quality (low, regular, good and very good). Furthermore, the farms were classified as NT or NTS. For classification as NTS, the following conditions were cumulatively considered: (1) adoption of no soil mobilization for a period longer than six years; (2) cultivation of four or more grasses for three years; and (3) cultivation of three or more different plant families for three years. These criteria were established from the critical levels established for the RD, PS and TF indicators, with values greater than $0.67,0.5$ and 0.5 , respectively.

Analyzing the individual scores and classifications (Table 4), three cases $(8.1 \%)$ were observed with PQI classified as very good, 26 cases (70.3\%) as good, and eight cases $(21.6 \%)$ as regular and no low. Adding the very good and good classes together, a score of $78.4 \%$ was found, demonstrating that the majority had a satisfactory classification, which was corroborated by the average PQI of 7.12 (Table 4), classified as good. By evaluating the PQI of 40 farms in western Paraná, Nunes et al. (2020b) found values of $5,57.5,27.5$ and $10 \%$ for very good, good, regular, and low areas, respectively, with lower percentages of good and very good PQI values compared to those observed in the present study. In a similar study conducted on six farms in southwestern Paraná, Mendes et al. (2019) observed $50 \%$ good ratings and $50 \%$ regular ratings. Telles et al. (2020) found an average PQI of 6.63 for 121 farms in western Paraná, also classified as good, similar to the PQI calculated in southwest Paraná.

The highest PQI was observed in farm 14 with a score of 8.68, while the lowest was observed in farm 7 with a score of 5.08 . A coefficient of variation of $12.4 \%$ was calculated among the 37 farms (Table 4), demonstrating a great variation between their corresponding scores. This amplitude was also observed in Paraná Basin 3, when the methodology was first used with 25 farms, ranging from 9.7 to 4.8 (Itaipu Binacional and Febrapdp, 2011), and in 121 farms ranging from 9.0 to 3.37 (Telles et al., 2020).

The general average of the eight indicators that make up PQI (Table 4), compared to the critical levels (Table 2 ), indicated that none of these presented a value below the critical level. That is, the indicators presented a behavior above the restrictive limit to NTS on average. However, an individual analysis of the indicators helps to understand better the outcomes of the management practices adopted.

The RI presented an average score of 0.90 (Table 4), which corresponds to 32.4 months with cultures in three years, similar to the average of 0.867 obtained by Telles et al. (2020) when analyzing 121 areas in western Paraná. There were no cases with a score below the critical limit, and five cases ( $13.5 \%$ ) had the ideal value. The surveys indicated an average of 2.4 crops in each year (Table 3), which is desirable in the NTS with the proposal of the harvest-sowing system, with a reduction or suppression of the interval between harvest and subsequent sowing (Denardin et al., 2012). 
Table 3. General characterization of the farms, municipalities, total area of annual crops, time of no-tillage adoption, and cultivations of the last three years in southwestern Paraná

\begin{tabular}{|c|c|c|c|c|c|c|}
\hline \multirow{2}{*}{ Farms } & \multirow{2}{*}{ Municipality } & \multirow{2}{*}{ Area } & \multirow{2}{*}{ Adoption time } & \multicolumn{3}{|c|}{ Cultivations } \\
\hline & & & & Harvest $18 / 19$ & Harvest $17 / 18$ & Harvest $16 / 17$ \\
\hline & & ha & year & & & \\
\hline 1 & $\begin{array}{l}\text { Bela Vista da } \\
\text { Caroba }\end{array}$ & 36.3 & 18 & $\begin{array}{c}\text { Soybean / Millet } \\
\text { Wheat }\end{array}$ & $\begin{array}{c}\text { Soybean / } \text { grass }^{(1)} / \\
\text { Wheat }\end{array}$ & $\begin{array}{l}\text { Soybean / Corn / } \\
\text { Black oats }^{(1)}\end{array}$ \\
\hline 2 & $\begin{array}{l}\text { Boa Esperança } \\
\text { do Iguaçu }\end{array}$ & 7.0 & 9 & $\begin{array}{l}\text { Soybean / Corn / Black } \\
\text { oats }^{(1)}\end{array}$ & $\begin{array}{l}\text { Soybean / Corn / } \\
\text { Turnip }^{(1)}\end{array}$ & $\begin{array}{l}\text { Soybean / Corn / } \\
\text { Black oats }^{(1)}\end{array}$ \\
\hline 3 & Capanema & 11.7 & 19 & Soybean / Urochloa ${ }^{(1)}$ & Soybean / Corn & Soybean / Corn \\
\hline 4 & Chopinzinho & 48.0 & 9 & $\begin{array}{l}\text { Soybean / Corn / } \\
\text { forage turnip }^{(1)}\end{array}$ & $\begin{array}{l}\text { Soybean / Millet }{ }^{(1)} / \\
\text { Black oats }^{(1)}\end{array}$ & $\begin{array}{l}\text { Soybean / Millet }{ }^{(1)} / \\
\text { Buckwheat }^{(1)}\end{array}$ \\
\hline 5 & Chopinzinho & 7.5 & 20 & Soybean / Black oats ${ }^{(1)}$ & $\begin{array}{l}\text { Corn }^{(2)} / \text { Millet }^{(1)} / \\
\text { Black oats }^{(1)}\end{array}$ & Soybean / Black oats ${ }^{(1)}$ \\
\hline 6 & Chopinzinho & 20.5 & 17 & $\begin{array}{l}\text { Soybean / Bean / } \\
\text { Black oats }^{(1)}\end{array}$ & $\begin{array}{l}\text { Soybean / Bean / } \\
\text { Black oats }^{(1)}\end{array}$ & $\begin{array}{l}\text { Soybean / Bean / } \\
\text { Black oats }^{(1)}\end{array}$ \\
\hline 7 & Clevelândia & 38.7 & 8 & Soybean / Bean & Soybean / Black oats ${ }^{(1)}$ & Soybean / Black oats ${ }^{(1)}$ \\
\hline 8 & Enéas Marques & 25.0 & 15 & Soybean / Wheat & Soybean / Wheat & Soybean / Wheat \\
\hline 9 & Honório Serpa & 7.3 & 18 & Soybean / Black oats ${ }^{(1)}$ & Soybean / Black oats ${ }^{(1)}$ & $\begin{array}{l}\text { Corn }^{(2)} / \text { Corn / } \\
\text { Black oats }^{(1)}\end{array}$ \\
\hline 10 & Itapejara d'Oeste & 13.3 & 24 & $\begin{array}{l}\text { Soybean / Bean / } \\
\text { Black oats }^{(1)}\end{array}$ & $\begin{array}{l}\text { Soybean / Bean / } \\
\text { Black oats }^{(1)}\end{array}$ & $\begin{array}{l}\text { Soybean / Bean / } \\
\text { Black oats }^{(1)}\end{array}$ \\
\hline 11 & Itapejara d'Oeste & 12.1 & 17 & Soybean / Corn & Soybean / Corn & $\begin{array}{l}\text { Soybean / Soybean / } \\
\text { Black oats }\end{array}$ \\
\hline 12 & Itapejara d'Oeste & 242.0 & 20 & Soybean / Black oats ${ }^{(1)}$ & $\begin{array}{l}\text { Soybean / Bean / } \\
\text { Black oats }^{(1)}\end{array}$ & $\begin{array}{l}\text { Soybean / Corn / } \\
\text { Black oats }^{(1)}\end{array}$ \\
\hline 13 & Mariópolis & 5.4 & 10 & $\begin{array}{l}\text { Soybean / Millet } \\
\text { Black oats }^{(1)}\end{array}$ & $\begin{array}{l}\text { Soybean / forage } \\
\text { turnip }^{(1)}\end{array}$ & Soybean / Black oats ${ }^{(1)}$ \\
\hline 14 & Mariópolis & 12.1 & 29 & Corn / Black oats ${ }^{(1)}$ & Soybean / Black oats ${ }^{(1)}$ & $\begin{array}{l}\text { Corn }^{(2)} / \text { Millet }^{(1)} / \\
\text { Black oats }^{(1)}\end{array}$ \\
\hline 15 & Marmeleiro & 20.0 & 10 & Soybean / Black oats ${ }^{(1)}$ & $\begin{array}{l}\text { Soybean / Millet } \\
\text { Black oats }^{(1)} /\end{array}$ & Soybean / Black oats ${ }^{(1)}$ \\
\hline 16 & Marmeleiro & 42.0 & 15 & $\begin{array}{l}\text { Soybean / Corn / } \\
\text { Ryegrass }^{(1)}\end{array}$ & Soybean / Wheat & Soybean / Black oats ${ }^{(1)}$ \\
\hline 17 & $\begin{array}{l}\text { Nova Esperança } \\
\text { do Sudoeste }\end{array}$ & 16.9 & 4 & Soybean / Corn & $\begin{array}{l}\text { Soybean / Corn } \\
\text { Black oats }^{(2)}\end{array}$ & Soybean / Corn \\
\hline 18 & $\begin{array}{l}\text { Nova Prata do } \\
\text { Iguaçu }\end{array}$ & 24.2 & 15 & Soybean / Wheat & Soybean / Wheat & Soybean / Wheat \\
\hline 19 & $\begin{array}{l}\text { Nova Prata do } \\
\text { Iguaçu }\end{array}$ & 7.2 & 18 & Soybean / Corn & $\begin{array}{l}\text { Soybean / forage } \\
\text { turnip }^{(1)}\end{array}$ & Soybean / Black oats ${ }^{(1)}$ \\
\hline 20 & $\begin{array}{l}\text { Nova Prata do } \\
\text { Iguaçu }\end{array}$ & 29.0 & 20 & $\begin{array}{c}\text { Soybean / } \mathrm{Mix}^{(1)} / \\
\text { Wheat }\end{array}$ & Soybean / Corn & Soybean / Wheat \\
\hline 21 & Pato Branco & 80.0 & 15 & Soybean / Black oats ${ }^{(1)}$ & Soybean / White oats & Corn / Bean / Wheat \\
\hline 22 & Pato Branco & 5.0 & 20 & Soybean / Black oats ${ }^{(1)}$ & $\begin{array}{l}\text { Soybean / Millet }{ }^{(1)} / \\
\text { Black oats }\end{array}$ & Soybean / Black oats ${ }^{(1)}$ \\
\hline 23 & Pato Branco & 10.9 & 10 & $\begin{array}{l}\text { Soybean / Bean / } \\
\text { Black oats }^{(1)}\end{array}$ & Soybean / Black oats ${ }^{(1)}$ & Soybean / Wheat \\
\hline 24 & Planalto & 5.0 & 5 & Soybean / Black oats ${ }^{(1)}$ & Soybean / Black oats ${ }^{(1)}$ & Soybean / Black oats ${ }^{(1)}$ \\
\hline 25 & Pranchita & 24.0 & 20 & Soybean / Black oats ${ }^{(1)}$ & Soybean / Black oats ${ }^{(1)}$ & Soybean / Black oats ${ }^{(1)}$ \\
\hline 26 & Realeza & 22.5 & 20 & $\begin{array}{l}\text { Soybean / Forage } \\
\text { turnip }^{(1)}\end{array}$ & Corn / Wheat & Soybean / Wheat \\
\hline 27 & Renascença & 15.0 & 21 & $\begin{array}{l}\text { Corn / Bean / } \\
\text { Black oats }^{(1)}\end{array}$ & $\begin{array}{c}\text { Soybean / Grass }{ }^{(1)} / \\
\text { Black oats }^{(1)}\end{array}$ & Soybean / Black oats ${ }^{(1)}$ \\
\hline 28 & Salto do Lontra & 41.1 & 10 & Soybean / Corn & Soybean / Corn & Soybean / Corn \\
\hline
\end{tabular}


Continuation

\begin{tabular}{|c|c|c|c|c|c|c|}
\hline 29 & Salto do Lontra & 11.1 & 19 & $\begin{array}{c}\text { Soybean / Millet } \\
\text { Wheat }\end{array}$ & Soybean / Black oats ${ }^{(1)}$ & Corn / Wheat \\
\hline 30 & Salto do Lontra & 41.1 & 11 & Soybean / Wheat & Soybean / Black oats ${ }^{(1)}$ & Corn / Black oats ${ }^{(1)}$ \\
\hline 31 & Salto do Lontra & 17.0 & 10 & $\begin{array}{l}\text { Soybean / Millet } \\
\text { Forage turnip }^{(1)}\end{array}$ & $\begin{array}{c}\text { Soybean / Millet } \\
\text { Wheat }\end{array}$ & Corn / Wheat \\
\hline 32 & São João & 17.0 & 30 & $\begin{array}{c}\text { Soybean / Corn / } \\
\text { Wheat }\end{array}$ & Soybean / Corn & Soybean / Corn \\
\hline 33 & São João & 9.0 & 32 & Soybean / Black oats ${ }^{(1)}$ & Soybean / Black oats ${ }^{(1)}$ & Soybean / Corn \\
\hline 34 & $\begin{array}{l}\text { São Jorge do } \\
\text { Oeste }\end{array}$ & 7.3 & 15 & $\begin{array}{l}\text { Soybean / Corn / } \\
\text { Black oats }^{(1)}\end{array}$ & Soybean / Corn & Soybean / Corn \\
\hline 35 & $\begin{array}{l}\text { São Jorge do } \\
\text { Oeste }\end{array}$ & 12.1 & 0 & $\begin{array}{l}\text { Soybean / Corn / } \\
\text { Black oats }^{(1)}\end{array}$ & $\begin{array}{l}\text { Soybean / Corn / } \\
\text { Black oats }^{(1)}\end{array}$ & $\begin{array}{l}\text { Soybean / Bean / } \\
\text { Black oats }^{(1)}\end{array}$ \\
\hline 36 & Vitorino & 18.2 & 20 & $\begin{array}{l}\text { Soybean / Corn / } \\
\text { Black oats }^{(1)}\end{array}$ & $\begin{array}{l}\text { Soybean / Bean / } \\
\text { Black oats }^{(1)}\end{array}$ & $\begin{array}{l}\text { Soybean / Bean / } \\
\text { Black oats }^{(1)}\end{array}$ \\
\hline \multirow[t]{2}{*}{37} & Vitorino & 13.3 & 25 & Soybean / Black oats ${ }^{(1)}$ & Soybean / Wheat & $\begin{array}{l}\text { Soybean / Corn / } \\
\text { Black oats }^{(1)}\end{array}$ \\
\hline & Mean & 26.4 & 16.2 & - & - & - \\
\hline
\end{tabular}

${ }^{(1)}$ Cover crop cultivation. ${ }^{(2)}$ Crops harvesting for silage.

For DR, the average was 0.73 (Table 4), above the critical level and corresponding to the cultivation of 2.19 botanical families in three years. Only seven cases $(18.9 \%)$ achieved an ideal score, and the majority $(81.1 \%)$ had a score equal to the critical level (Table 4), indicating that DR can be a limiting factor in the NTS quality, especially with the predominance of soybean cultivation in the first crop by $91.3 \%$ over the three years (Table 3). Telles et al. (2020) observed an average DR of 0.59 in western Paraná, which is below the value of this study. It is worth noting that Nunes et al. (2020b) concluded that crop rotation, assessed by the $\mathrm{DR}$, is the main management practice that contributes to the NTS quality assessed by the PQI, showing a good correlation with the SOM.

For PS, an average of 0.62 was obtained above the critical level, corresponding to 3.72 grass crops in three years (Table 4$)$. In 20 cases ( $54.1 \%$ ), the values obtained were found to be above the critical level; in two cases (5.4\%) below the critical level; and in 15 cases $(40.5 \%)$, the values were equal to the critical level, indicating that approximately half of the cases may have insufficient or critical coverage. However, there was a predominance of soybeans in the first crop in $91.3 \%$ of the cases (Table 3), indicating a low adoption of grass cultivation in the first crop, which is recommended in at least $25-30 \%$ of the areas with corn in a system of rotation, providing a greater straw production and a higher $\mathrm{C} / \mathrm{N}$ ratio (Franchini et al., 2011b; Canalli et al., 2019). The mean obtained in this study is greater than the mean of 0.55 obtained by Telles et al. (2020) in western Paraná.

The TF averaged 0.89 (Table 4), which was above the critical level, demonstrating that soil mobilization is not a recurrent practice in these farms. In 19 cases $(51.4 \%)$, the ideal score was obtained, corresponding to no soil disturbance in the last 12 years, one case $(2.7 \%)$ with a score below the critical level, and 17 cases $(45.9 \%)$ with partial preparation of the area; the latter was only observed in areas used for maneuvering machines, known as "headboards." It is worth noting that the diagnosed farms were composed of an average of 20.3 hectares (Table 3), characterized as a small area, where the need for maneuvers for mechanized operations increases. Telles et al. (2020) found a lower mean in surveys in western Paraná, with an average of 0.63 TF.

The CT had an average of 0.54 , above the critical level (Table 4), with 17 cases (45.9\%) presenting the ideal condition, with the presence of the terrace and at most one overflow in the last five years, and 14 cases $(37.8 \%)$ with no terrace or with overflow more than three times in the last five years. The presence of terracing was mentioned in 26 cases 
Table 4. Values of indicators, PQI values, and classifications as no-tillage (NT) or no-tillage system (NTS) in each farm evaluated

\begin{tabular}{|c|c|c|c|c|c|c|c|c|c|c|c|}
\hline \multirow{2}{*}{ Farms } & \multicolumn{8}{|c|}{ Indicators $^{(1)}$} & \multirow{2}{*}{ PQI } & \multirow{2}{*}{$\begin{array}{c}\text { PQI } \\
\text { classification }\end{array}$} & \multirow{2}{*}{$\begin{array}{c}\text { NT } \times \text { NTS } \\
\text { classification }\end{array}$} \\
\hline & $\mathbf{R I}$ & RD & PS & TF & CT & SC & BF & AT & & & \\
\hline 1 & 0.83 & 0.67 & 1.00 & 1.00 & 0.00 & 0.50 & 0.00 & 0.72 & 6.47 & regular & NT \\
\hline 2 & 1.00 & 1.00 & 0.83 & 1.00 & 1.00 & 0.75 & 0.50 & 0.36 & 8.36 & good & NTS \\
\hline 3 & 0.86 & 0.67 & 0.50 & 0.80 & 0.50 & 0.68 & 0.75 & 0.76 & 6.93 & good & NT \\
\hline 4 & 0.92 & 1.00 & 0.67 & 0.80 & 1.00 & 0.43 & 1.00 & 0.36 & 7.86 & good & NT \\
\hline 5 & 0.94 & 0.67 & 0.67 & 0.80 & 1.00 & 0.75 & 0.75 & 0.80 & 7.92 & good & NT \\
\hline 6 & 0.94 & 0.67 & 0.50 & 0.80 & 0.00 & 0.18 & 0.75 & 0.68 & 5.97 & regular & NT \\
\hline 7 & 0.89 & 0.67 & 0.33 & 1.00 & 0.00 & 0.18 & 0.25 & 0.32 & 5.08 & regular & NT \\
\hline 8 & 0.89 & 0.67 & 0.50 & 1.00 & 0.00 & 0.18 & 0.50 & 0.60 & 5.86 & regular & NT \\
\hline 9 & 1.00 & 0.67 & 0.67 & 0.80 & 0.00 & 0.50 & 0.25 & 0.72 & 6.17 & regular & NT \\
\hline 10 & 1.00 & 0.67 & 0.50 & 1.00 & 1.00 & 0.25 & 0.50 & 0.96 & 7.46 & good & NT \\
\hline 11 & 0.89 & 0.67 & 0.50 & 1.00 & 1.00 & 0.50 & 0.25 & 0.68 & 7.01 & good & NT \\
\hline 12 & 1.00 & 0.67 & 0.67 & 1.00 & 1.00 & 1.00 & 0.75 & 0.80 & 8.55 & very good & NT \\
\hline 13 & 0.86 & 1.00 & 0.50 & 1.00 & 0.00 & 0.68 & 1.00 & 0.40 & 7.12 & good & NT \\
\hline 14 & 0.83 & 0.67 & 0.83 & 1.00 & 1.00 & 0.68 & 1.00 & 1.00 & 8.68 & very good & NT \\
\hline 15 & 0.86 & 0.67 & 0.67 & 0.80 & 0.00 & 0.43 & 0.25 & 0.40 & 5.57 & regular & NT \\
\hline 16 & 0.83 & 0.67 & 0.67 & 1.00 & 0.00 & 0.75 & 0.75 & 0.60 & 6.85 & good & NT \\
\hline 17 & 0.86 & 0.67 & 0.50 & 0.80 & 0.00 & 0.25 & 1.00 & 0.16 & 5.65 & regular & NT \\
\hline 18 & 0.83 & 0.67 & 0.50 & 0.80 & 1.00 & 0.50 & 0.50 & 0.60 & 6.80 & good & NT \\
\hline 19 & 0.92 & 1.00 & 0.33 & 0.80 & 0.50 & 0.50 & 0.25 & 0.72 & 6.55 & good & NT \\
\hline 20 & 0.89 & 1.00 & 0.50 & 0.80 & 0.50 & 0.50 & 0.50 & 0.80 & 7.08 & good & NT \\
\hline 21 & 0.94 & 0.67 & 0.67 & 1.00 & 0.00 & 0.43 & 0.75 & 0.60 & 6.69 & good & NT \\
\hline 22 & 0.94 & 0.67 & 0.67 & 0.80 & 1.00 & 0.68 & 1.00 & 0.80 & 8.09 & good & NT \\
\hline 23 & 0.89 & 0.67 & 0.50 & 0.80 & 1.00 & 0.75 & 0.75 & 0.40 & 7.18 & good & NT \\
\hline 24 & 0.89 & 0.67 & 0.50 & 1.00 & 0.00 & 0.50 & 1.00 & 0.20 & 6.28 & regular & NT \\
\hline 25 & 0.92 & 0.67 & 0.50 & 1.00 & 0.50 & 0.50 & 1.00 & 0.80 & 7.43 & good & NT \\
\hline 26 & 0.75 & 1.00 & 0.50 & 0.25 & 1.00 & 0.68 & 1.00 & 0.80 & 7.23 & good & NT \\
\hline 27 & 0.92 & 0.67 & 0.83 & 0.80 & 1.00 & 0.75 & 0.75 & 0.84 & 8.17 & good & NT \\
\hline 28 & 0.83 & 0.67 & 0.50 & 1.00 & 1.00 & 0.75 & 0.50 & 0.40 & 7.15 & good & NT \\
\hline 29 & 0.92 & 0.67 & 0.83 & 1.00 & 0.00 & 0.50 & 0.75 & 0.76 & 7.14 & good & NT \\
\hline 30 & 0.81 & 0.67 & 0.67 & 1.00 & 0.50 & 0.50 & 0.75 & 0.44 & 6.90 & good & NT \\
\hline 31 & 0.94 & 1.00 & 0.83 & 1.00 & 1.00 & 0.50 & 1.00 & 0.40 & 8.57 & very good & NTS \\
\hline 32 & 0.89 & 0.67 & 0.67 & 1.00 & 0.50 & 0.50 & 0.50 & 1.00 & 7.33 & good & NT \\
\hline 33 & 0.83 & 0.67 & 0.50 & 0.80 & 1.00 & 0.25 & 0.75 & 1.00 & 7.20 & good & NT \\
\hline 34 & 0.89 & 0.67 & 0.67 & 1.00 & 0.00 & 1.00 & 0.75 & 0.60 & 7.18 & good & NT \\
\hline 35 & 1.00 & 0.67 & 0.83 & 0.80 & 1.00 & 1.00 & 1.00 & 0.40 & 8.35 & good & NT \\
\hline 36 & 0.86 & 0.67 & 0.67 & 0.80 & 0.00 & 0.50 & 1.00 & 0.80 & 6.79 & good & NT \\
\hline 37 & 0.89 & 0.67 & 0.67 & 0.80 & 1.00 & 0.43 & 0.75 & 1.00 & 7.71 & good & NT \\
\hline Mean & 0.90 & 0.73 & 0.62 & 0.89 & 0.54 & 0.55 & 0.69 & 0.64 & 7.12 & good & - \\
\hline CV (\%) & 6.6 & 18.1 & 24.5 & 16.5 & 85.5 & 39.7 & 40.5 & 36.5 & 12.4 & - & - \\
\hline
\end{tabular}

${ }^{(1)} \mathrm{RI}$ (crop rotation intensity), RD (crop rotation diversity), PS (persistence of straw), TF (soil tillage frequency), CT (correct terracing), SC (soil conservation evaluation), BF (balanced soil fertilization), AT (adoption time).

(70.3\%), in which $65 \%$ had a maximum of one overflow, $23 \%$ between two or three overflows, and $12 \%$ with more than three overflows in the last five years; in these two situations, there could be problems related to the dimensioning of terraces or even problems of low water infiltration in the soils due to compaction. Terracing on farms is 
an important practice to prevent soil erosion and increase water infiltration in the soil (Franchini et al., 2009). Telles et al. (2020) observed an average of 0.71 for CT in western Paraná, which is higher than the value found in this study.

For SC, the average was 0.55 , which was above the critical level, with three cases (8.1\%) having an ideal score, 13 cases ( $35.1 \%$ ) with a score equal to the critical level, and 10 cases $(27.0 \%)$ with scores below the critical level. The sum of scores equal to or below the critical level was $62.2 \%$, demonstrating that SC can limit NTS quality in the region. Among the surveys, $97 \%$ reported sowing at level, which indicates a good adoption of this practice, contributing to fewer problems arising from erosion in seeding furrows, but only $65 \%$ indicated spraying at level in the fields. In the evaluation of soil compaction, only $24 \%$ indicated that there would be no soil compaction in the area, $22 \%$ indicated compaction throughout the tract, and $54 \%$ indicated only compaction in the headland, adding up to $76 \%$ of compaction indications. For erosion, only $30 \%$ did not mention the presence of signs of erosion, and the remaining $70 \%$ mentioned the presence of erosion from inside the plot (32\%) or from outside the plot (38\%). It is worth noting that most cases of soil compaction and erosion problems were observed in these areas. Telles et al. (2020) found a higher SC value in western Paraná, with an average of 0.694 .

For BF, the average was 0.69 (Table 4), which was above the critical level, with 24 cases (64.9\%) having an ideal score or above the critical level, seven (18.9\%) scoring equal to the critical level, and six (16.2\%) with scores below the critical level. In 27 cases (73.0 \%), animal manure, whether swine, cattle, or poultry, was used as fertilizer; however, among these, only six cases used manure based on the results of soil analysis and nutrient balance. Regarding chemical fertilization, the practice adopted by all cases studied, 26 cases (70.3\%) used fertilization based on the results of the soil analysis. In terms of liming, this percentage rose to $86.5 \%$, with a history of using limestone every four years. In western Paraná, Telles et al. (2020) found a value of 0.59 for BF, which is below the value found in this work.

For AT, the average value was 0.63 (Table 4), which is higher than the critical level. Three cases $(8.1 \%)$ had a value below the critical level, and only four cases (10.8\%) had an ideal situation with 25 or more years of NTS adoption. On average, there was a time of adoption of 16.2 years, similar to that obtained by Mendes et al. (2019) for a southwestern municipality with 13.3 years. Telles et al. (2020) found an average AT of 0.67 in western Paraná, demonstrating a similarity between the adoption times in the two regions. Most of the farms evaluated (54.1\%) adopted the NTS between 10 and 20 years, which is considered the consolidation phase of the NTS (Debiasi et al., 2013; Sá et al., 2019a).

Individual analysis of PQI indicators suggests restrictive situations in NTS quality for $\mathrm{RD}, \mathrm{SP}, \mathrm{CT}$ and $\mathrm{SC}$, highlighting the low diversification of cultivated species, the low use of grasses for straw formation, the incorrect use of terracing, the presence of soil compaction and erosion, and the difficulty in establishing a crop rotation system with the use of species with the potential to promote good soil cover. Thus, these are likely to be the greatest challenges in these areas.

When classifying the farms as NT or NTS (Table 4), we noted that only two cases (5.4\%) were classified as NTS, agreeing with the three principles simultaneously, while the rest did not meet one or more principles. Nunes et al. (2020a) found $10.3 \%$ of NTS among farms evaluated by the PQI methodology in western Paraná, a percentage higher than that in this study. Thus, the adoption of NTS in this study is limited to $5 \%$ of farms, which corroborates the estimate that most of the area in use in Brazil is NT and not NTS.

The two cases classified as NTS had PQI scores above eight, classifying them as good and very good quality. At the same time, 25 cases $(67.5 \%)$ were classified as NTS with good quality, but were classified as NT. This result demonstrates the weakness of the 
tool by classifying as good quality the cases of farms that do not adopt all three NTS principles, not fully complying with its initial proposal for evaluating the NTS.

Therefore, the PQI methodology must be suitable for each case, adopting the criteria and weights recommended by regional studies, and can be improved to differentiate NT from NTS. The NT characterizes the partial adoption of NTS fundamentals, aiming to obtain the maximum quality in the production system, which is the situation that gives rise to the benefits of this technology at the level of the farmer and society, including a higher and more stable productivity, better adaptation to climate change, a reduction of greenhouse gas emissions, and enhanced ecosystem services in general (Derpsch et al., 2010).

In this way, PQI can be used to make this distinction, considering, for example, as NTS only a PQI that is classified as good and very good, as long as it does not have a score equal to or lower than the critical limit for RD, SP, and TF. Furthermore, adjustments in the input data, calculation formulas, and critical limits of RD, SP and TF are necessary for these three indicators to characterize the adoption of crop rotation, permanent soil cover via the addition of plant residues, minimal soil disturbance and NTS principles.

\section{CONCLUSIONS}

Due to the range profusion of terminologies related to the topic "Plantio Direto" in Brazil, standardization of its current use in the literature is required, which includes a clear definition of concepts underlying the practical application of these terms. While "Plantio Direto" is a conservationist practice, "Sistema Plantio Direto" presents itself as an agricultural production system based on the simultaneous adoption of minimum soil disturbance, the maintenance of permanent soil cover and crop rotation. These definitions have implications for research, teaching, extension and public policy.

The data on the cultivated area under no-tillage system (NTS) or no-tillage (NT) need to be segmented in official surveys, considering that they could be understood as effectively different practices, so they cease to be estimated and become official numbers that can be reliably cited.

It is estimated that less than $10 \%$ of the area cultivated with grains in the Paraná State adopts crop rotation and could thus be characterized as NTS, given the predominance of successions of soybean/corn and soybean/wheat crops.

Participatory quality index (PQI) is an efficient tool for analyzing NTS quality, with indicators capable of discriminating the practices adopted by farmers, but requiring adjustments in their weights; thus, the final grade and classification effectively reflects the differentiation between NT and NTS, as well as regionalizing the methodology based on local studies given the different environmental, social and economic conditions of agriculture in Paraná and Brazil more broadly.

\section{ACKNOWLEDGEMENTS}

We thank the Institute of Rural Development of Paraná - IAPAR-EMATER, the extension rural and farmers participating in the research. We also thank National Council for Scientific and Technological Development - Brazil (CNPq) and Coordination for the Improvement of Higher Education Personnel - Brazil (CAPES).

\section{AUTHOR CONTRIBUTIONS}

Conceptualization: (D) Caroline Amadori (equal), (D) Edivan José Possamai (equal) and (D) Paulo Cesar Conceição (equal). 
Data curation: (DD Edivan José Possamai (equal), (D) Marie Louise Carolina Bartz (supporting) and (iD Paulo Cesar Conceição (equal).

Formal analysis: (D) Caroline Amadori (equal), (D) Edivan José Possamai (equal) and (D) Paulo Cesar Conceição (equal).

Investigation: (D) Edivan José Possamai (equal), (D) Ericson Fagundes Marx (supporting) and (D) Marcelo Vicensi (supporting).

Methodology: (D) Edivan José Possamai (equal), (D) Ericson Fagundes Marx (supporting), (ID) Marcelo Vicensi (supporting), (D) Marie Louise Carolina Bartz (supporting) and (ID) Paulo Cesar Conceição (equal).

Project administration: (D) Edivan José Possamai (lead).

Validation: (D) Edivan José Possamai (lead).

Visualization: (D) Ricardo Ralisch (supporting).

Writing - original draft: (D) Caroline Amadori (equal), (D) Edivan José Possamai (equal), (D) Marie Louise Carolina Bartz (supporting) and (iD Paulo Cesar Conceição (equal).

Writing - review \& editing: (D) Caroline Amadori (equal), (D) Edivan José Possamai (equal), (D) Marie Louise Carolina Bartz (supporting), (D) Paulo Cesar Conceição (equal) and (iD Ricardo Ralisch (supporting).

\section{REFERENCES}

Alves VB, Padilha NS, Garcia RA, Ceccon G. Milho safrinha consorciado com Urochloa ruziziensis e produtividade da soja em sucessão. Rev Bras Milho Sorgo. 2013;12:280-92. https://doi.org/10.18512/1980-6477/rbms.v12n3p280-292

Aratani RG. Estudo exploratório dos termos "plantio direto" e "semeadura direta" e suas variações em bases de dados bibliográficas. Res Soc Dev. 2020;9:e129985533. https://doi.org/10.33448/rsd-v9i8.5533

Balota EL, Calegari A, Nakatani AS, Coyne MS. Benefits of winter cover crops and no-tillage for microbial parameters in a Brazilian Oxisol: A long-term study. Agr Ecosyst Environ. 2014;197:31-40. https://doi.org/10.1016/j.agee.2014.07.010

Bertalanffy L. Teoria Geral dos Sistemas - Fundamentos, desenvolvimento e aplicações. 5 ed. Petrópolis, RJ: Vozes; 2010.

Bertol I, Cogo NP, Barbosa FT, Schick J. Manejo e conservação do solo e da água no Brasil: retrospectiva e projeção para o futuro. In: Leite LFC, Maciel GA, Araújo ASF, editors. Agricultura conservacionista no Brasil. Brasília, DF: Embrapa; 2014. p. 43-68.

Bertoni J, Lombardi Neto F. Conservação do Solo. 9 ed. São Paulo: Ícone; 2014.

Bolliger A, Magid J, Amado JCT, Skóra Neto F, Ribeiro MFS, Calegari A, Ralisch R, Neergaard A. Taking stock of the Brazilian "Zero-Till Revolution": A review of landmark research and farmers' practice. Adv Agron. 2006;91:47-110. https://doi.org/10.1016/S0065-2113(06)91002-5

Calegari A. Plantas de cobertura. In: Casão Junior R, Siqueira R, Mehta YR, Passini JJ, editors. Sistema plantio direto com qualidade. Londrina: lapar / Foz do Iguaçú: Itaipu Binacional; 2006. p. 55-73.

Calegari A, Ferro M, Grzestuk F, Jacinto Junior L. Plantio direto e rotação de culturas. Experiência em Latossolo Roxo - 1985-1992. Floresta: lapar, Cocamar, Zeneca; 1992.

Calegari A, Heckler JC, Santos HP, Pitol C, Fernandes FM, Hernani LC, Gaudencio CA. Culturas, sucessões e rotações. In: Salton JC, Hernani LC, Fontes CZ, editors. Sistema plantio direto: o produtor pergunta, a Embrapa responde. Dourados: Embrapa - CPAO; 1998. p. 59-80. 
Canalli LBS, Bordin I. Rotação de culturas. In: Bertol OJ, Colozzi Filho A, Barbosa GMC, Santos JB, Guimarães MF, editors. Manual de manejo e conservação do solo e da água para o estado do Paraná. Curitiba: NEPAR-SBCS; 2019. p. 129-32.

Canalli LBS, Conceição PC, Cassol C. Produção de Biomassa. In: Bertol OJ, Colozzi Filho A, Barbosa GMC, Santos JB, Guimarães MF, editors. Manual de manejo e conservação do solo e da água para o estado do Paraná. Curitiba: NEPAR-SBCS; 2019. p. 133-7.

Carvalho AM, Bustamante MMC, Sousa Junior JGA, Vivaldi LJ. Decomposição de resíduos vegetais em Latossolo sob cultivo de milho e plantas de cobertura. Rev Bras Cienc Solo. 2008;32:2831-8. https://doi.org/10.1590/S0100-06832008000700029

Carvalho JLN, Cerri CEP, Cerri CC. SPD aumenta sequestro de carbono pelo solo. Visão Agrícola. 2009;9:132-5.

Casão R, Araújo AG, Llanillo RF. Plantio direto no Sul do Brasil - Fatores que facilitaram a evolução do sistema e o desenvolvimento da mecanização conservacionista. Londrina: lapar; 2012.

Cassol EA, Denardin JE, Kochhann RA. Sistema plantio direto: Evolução e implicações sobre a conservação do solo e da água. In: Ceretta CA, Silva LS, Reichert JM, editors. Tópicos em ciência do solo. Viçosa, MG: Sociedade Brasileira de Ciência do Solo; 2007. v. 5. p. 333-70.

Ceccon G, Staut LA, Sagrilo E, Machado LAZ, Nunes DP, Alves VB. Legumes and forage species sole or intercropped with corn in soybean-corn succession in midwestern Brazil. Rev Bras Cienc Solo. 2013;37:204-12. https://doi.org/10.1590/S0100-06832013000100021

Ceretta CA, Basso CJ, Flecha AMT, Pavinato PS, Vieira FCB, Mai MEM. Manejo da adubação nitrogenada na sucessão aveia preta/milho, no sistema plantio direto. Rev Bras Cienc Solo. 2002;26:163-71. https://doi.org/10.1590/S0100-06832002000100017

Conceição PC. Práticas conservacionistas edáficas. In: Bertol OJ, Colozzi Filho A, Barbosa GMC, Santos JB, Guimarães MF, editors. Manual de manejo e conservação do solo e da água para o estado do Paraná. Curitiba: NEPAR-SBCS; 2019. p. 144-5.

Conceição PC, Amado TJC, Mielniczuk J, Spagnollo E. Qualidade do solo em sistemas de manejo avaliada pela dinâmica da matéria orgânica e atributos relacionados. Rev Bras Cienc Solo. 2005;29:777-88. https://doi.org/10.1590/S0100-06832005000500013

Debiasi H, Franchini J, Conte O, Balbinot Junior A, Torres E, Saraiva O. Sistemas de preparo do solo: trinta anos de pesquisas na Embrapa Soja. Londrina: Embrapa Soja; 2013.

Demetrio WC, Ribeiro RH, Nadolny H, Bartz MLC, Brown GG. Earthworms in Brazilian no-tillage agriculture: Current status and future challenges. Eur J Soil Sci. 2020;71:988-1005. https://doi.org/10.1111/ejss.12918

Denardin JE. Compactação e adensamento de solo: Caracterização, origem, riscos, danos e soluções [internet]. Passo Fundo: Embrapa; 2018 [cited 2020 Mar 8]. Available from: https://www.embrapa.br/busca-de-noticias/-/noticia/31340322/artigo---compactacao-eadensamento-de-solo-caracterizacao-origem-riscos-danos-e-solucoes.

Denardin JE, Kochhann RA, Faganello A, Cogo NP. Agricultura conservacionista no Brasil: Uma análise do conceito à adoção. In: Leite LFC, Maciel GA, Araújo ASF, editors. Agricultura conservacionista no Brasil. Brasília, DF: Embrapa; 2014. p. 23-41.

Denardin JE, Kochhann RA, Faganello A, Santi A, Denardin NA, Wiethölter S. Diretrizes do sistema plantio direto no contexto da agricultura conservacionista. Passo Fundo: Embrapa Trigo; 2012. (Documentos 141).

Derpsch R, Franzluebbers AJ, Duiker SW, Reicosky DC, Koeller K, Friedrich T, Sturny WG, Sá JCM, Weiss K. Why do we need to standardize no-tillage research? Soil Till Res. 2014;137:16-22. https://doi.org/10.1016/j.still.2013.10.002

Derpsch R, Friedrich T, Kassam A, Hongwen L. Current status of adoption of no-till farming in the world and some of its main benefits. Int J Agric Biol Eng. 2010;3:1-25. https://doi.org/10.3965/j.issn.1934-6344.2010.01.001-025

Derpsch R, Sidiras N, Roth CH. Results of studies made from 1977 to 1984 to control erosion by cover crops and no-tillage techniques in Paraná, Brazil. Soil Till Res. 1986;8:253-63. https://doi.org/10.1016/0167-1987(86)90338-7 
Federação Brasileira de Plantio Direto na Palha - Febrapdp. O que é Sistema plantio direto? [internet] Ponta Grossa: Febrapdp; 2021 [cited 2021 Jul 25]. Available from: https://febrapdp.org.br/sistema-plantio-direto-o-que-e.

Federação Brasileira de Plantio Direto na Palha - Febrapdp. Sistema plantio direto [internet]. Ponta Grossa: Febrapdp; 2020a [cited 2020 Feb 22]. Available from: https://www. plantiodireto.org/content/sistema-plantio-direto.

Federação Brasileira de Plantio Direto na Palha - Febrapdp. Documentos - plantio direto [internet]. Ponta Grossa: Febrapdp; 2020b [cited 2020 Feb 16]. Available from: https://www.plantiodireto.org/documentos.

Federação Brasileira de Plantio Direto na Palha - Febrapdp. Memória de cálculo dos indicadores IQP [internet]. Ponta Grossa: Febrapdp; 2020c [cited 2020 Feb 22]. Available from: https://www. plantiodireto.org/sites/default/files/documentos/IQP2_Indicadores_memoria_de_ calculo.pdf.

Federação Brasileira de Plantio Direto na Palha - Febrapdp. Formulário IQP em planilha eletrônica [internet]. Ponta Grossa: Febrapdp; 2020d [cited 2020 Mar 5]. Available from: https://www. plantiodireto.org/sites/default/files/documentos/Planilha IQP completo.xIsx.

Ferreira AO, Amado TJC, Rice CW, Diaz DAR, Briedis C, Inagaki TM, Gonçalves DRP. Driving factors of soil carbon accumulation in Oxisols in long-term no-till systems of South Brazil. Sci Total Environ. 2018;622-623:735-42. https://doi.org/10.1016/j.scitotenv.2017.12.019

Food and Agriculture Organization - FAO. Conservation agriculture [internet]. Rome: Food and Agriculture Organization of the United Nations; 2017 [cited 2020 Feb 22]. Available from: http://www.fao.org/conservation-agriculture/en/.

Franchini JC, Costa JM, Debiasi H, Torres E. Importância da rotação de culturas para a produção agrícola sustentável no Paraná. Londrina: Embrapa Soja; 2011 a.

Franchini JC, Costa JM, Debiasi H. Rotação de culturas: prática que confere maior sustentabilidade à produção agrícola no Paraná. Piracicaba: International Plant Nutrition Institute - Brasil; 2011b. p. 1-13. (Informações agronômicas 134).

Franchini JC, Debiasi H, Balbinot Junior AA, Tonon BC, Farias JRB, Oliveira MCN, Torres E. Evolution of crop yields in different tillage and cropping systems over two decades in southern Brazil. F Crop Res. 2012;137:178-85. https://doi.org/10.1016/j.fcr.2012.09.003

Franchini JC, Debiasi H, Sacoman A, Nepomuceno AL, Farias JRB. Manejo do solo para redução das perdas de produtividade pela seca. Londrina: Embrapa Soja; 2009.

Freitas PL, Landers JN. The Transformation of agriculture in Brazil through development and adoption of zero tillage conservation agriculture. Int Soil Water Conserv Res. 2014;2:35-46. https://doi.org/10.1016/S2095-6339(15)30012-5

Fuentes-Llanillo R, Bartz MLC, Telles TS, Araújo AG, Amado TJC, Bartz HA, Calegari A, Capandeguy F, Cubilla MM, Dabalá L, Derpsch R, Friedrich T, Ginés MC, Hernández-Zamora J, Kassam A, Moriya K, Ralisch R, Ramírez E, Roggero D, Soares Junior D, Mendoza RT. Conservation agriculture in South America. In: Kassam A, editor. Advances in conservation agriculture. Volume 3: Adoption and spread. Cambridge: Burleigh Dodds Science Publishing; 2021a. (Burleigh Dodds Series in Agricultural Science, 104).

Fuentes-Llanillo R, Telles TS, Soares Junior D, Melo TR, Friedrich T, Kassam A. Expansion of no-tillage practice in conservation agriculture in Brazil. Soil Till Res. 2021b;208:104877. https://doi.org/10.1016/j.still.2020.104877

Gonçalves SL, Gaudencio CA, Franchini JC, Galerani PR, Garcia A. Rotação de culturas. Londrina: Embrapa Soja; 2007.

Guareschi RF, Pereira MG, Perin A. Carbono, nitrogênio e abundância natural de $813 \mathrm{c}$ e $\delta 15 \mathrm{n}$ em uma cronossequência de agricultura sob plantio direto no cerrado goiano. Rev Bras Cienc Solo. 2014;38:1135-42. https://doi.org/10.1590/S0100-06832014000400009

Heckler JC, Hernani LC, Pitol C. Palha. In: Salton JC, Hernani LC, Fontes CZ, editors. Sistema plantio direto: O produtor pergunta, a Embrapa responde. Dourados: Embrapa - CPAO; 1998. p. 37-49. 
Hernani LC, Salton JC. Conceitos. In: Salton JC, Hernani LC, Fontes CZ, editors. Sistema plantio direto: o produtor pergunta, a Embrapa responde. Dourados: Embrapa - CPAO; 1998. p. 15-20.

Instituto Paranaense de Desenvolvimento Econômico e Social - Ipardes. Perfil avançado das regiões [internet]. Curitiba: Ipardes; 2020 [cited 2020 Mar 22]. Available from: http://www.ipardes.pr.gov.br/Pagina/Perfil-Avancado-das-Regioes.

Instituto Paranaense de Desenvolvimento Econômico e Social - Ipardes. Sudoeste paranaense: Especificidades e diversidades [internet]. Curitiba: Ipardes; 2009 [cited $2020 \mathrm{Apr}$ 4]. Available from: http://www.ipardes.pr.gov.br/sites/ipardes/arquivos_restritos/files/documento/2019-09/ Sudoeste Paranaense_especificidades e diversidades_2009.pdf.

Itaipu Binacional, Federação Brasileira de Plantio Direto na Palha - Febrapdp. Metodologia participativa para avaliar a qualidade do plantio direto na bacia hidrográfica do Paraná III. Foz do Iguaçú: Itaipu Binacional, Febrapdp; 2011.

Kassam A, Friedrich T, Derpsch R. Global spread of conservation agriculture. Int J Environ Stud. 2019;76:29-51. https://doi.org/10.1080/00207233.2018.1494927

Maria IC, Bertol I, Drugowich MI. Práticas conservacionistas do solo e da água. In: Bertol I, Maria IC, Souza LS, editors. Manual de manejo e conservação do solo e da água. Viçosa, MG: Sociedade Brasileira de Ciência do Solo; 2019. p. 527-87.

Martins ALS, Conte O, Oliveira P, Dossa ÁA, Debiasi H, Santos JCF, Hernani LC, Ralisch R, Leonardo HCL, Lunardi L, Salton JC, Tomazi M, Pitol C, Bona FD, Boeira RC. Avaliação ex ante do índice de qualidade participativo do plantio direto ( IQP ) com produtores do Centro-Sul do Brasil. Rio de Janeiro: Embrapa Solos; 2018.

Medeiros GB, Calegari A. Rotação de culturas. In: Casão Junior R, Siqueira R, Mehta YR, Passini JJ, editors. Sistema plantio direto com qualidade. Londrina: lapar / Foz do Iguaçú: Itaipu Binacional; 2006. p. 135-41.

Medeiros GB, Calegari A, Gadêncio C. Rotação de culturas. In: Paraná Secretaria Estadual de Agricultura e Abastecimento, editor. Manual técnico do subprograma de manejo e conservação do solo. 2. ed. Curitiba: IAPAR; 1994. p. 186-95.

Mendes TA, Mello NA, Telles CS. O índice de qualidade participativo a partir da análise da qualidade do sistema de plantio direto: Um estudo de caso no município de Clevelândia (PR), Brasil. Rev Extensão Estud Rurais. 2019;8:103-22. https://doi.org/10.36363/rever812019103-122

Moraes MT, Debiasi H, Carlesso R, Franchini JC, Silva VR, Luz FB. Soil physical quality on tillage and cropping systems after two decades in the subtropical region of Brazil. Soil Till Res. 2016;155:351-62. https://doi.org/10.1016/j.still.2015.07.015

Motter P, Almeida HG, Valle D, Mello I. Plantio direto, a tecnologia que revolucionou a agricultura brasileira. Foz do Iguaçu: Parque Itaipu; 2015.

Muzilli O. Manejo do solo em sistema plantio direto. In: Casão Junior R, Siqueira R, Mehta YR, Passini JJ, editors. Sistema plantio direto com qualidade. Londrina: Iapar / Foz do Iguaçú: Itaipu Binacional; 2006. p. 9-27.

Nitsche PR, Caramori PH, Rice WS, Pinto LFD. Atlas Climático do Estado do Paraná [internet]. Londrina: IAPAR; 2019 [cited 2020 Apr 4]. Available from: http://www.idrparana.pr.gov.br/ system/files/publico/agrometeorologia/atlas-climatico/atlas-climatico-do-parana-2019.pdf.

Nunes ALP, Cortez GLS, Melo TR, Figueiredo A, Wandscheer CAR, Bortoluzzi J, Brown GG, Bartz MLC, Ralisch R, Guimarães MF. Farm systems, soil chemical properties, and clay dispersion in watershed areas. Pesq Agropec Bras. 2020a;55:e01279. https://doi.org/10.1590/S1678-3921.PAB2020.V55.01279

Nunes ALP, Bartz ML, Mello I, Bortoluzzi J, Roloff G, Llanillo RF, Canalli L, Wandscheer CAR, Ralisch R. No-till system participatory quality index in land management quality assessment in Brazil. Eur J Soil Sci. 2020b;71:974-87. https://doi.org/10.1111/ejss.12943

Organisation for Economic Co-operation and Development, Food and Agriculture Organization of the United Nations. OECD-FAO Agricultural Outlook 2015. Paris: OECD Publishing; 2015. https://doi.org/10.1787/agr_outlook-2015-en 
Paraná. Estimativa de safra [internet]. Curitiba: Secretaria da Agricultura e do Abastecimento; 2021 [cited 2021 Jul 2]. Available from: http://www.agricultura.pr.gov.br/deral/safras.

Passos AMA, Alvarenga RC, Santos FC. Sistema de plantio direto. In: Nobre MM, Oliveira IR, editors. Agricultura de baixo carbono: Tecnologias e estratégias de implantação. Brasilia, DF: Embrapa; 2018. p. 61-104.

Pereira Neto OC, Guimarães MF, Ralisch R, Fonseca ICB. Análise do tempo de consolidação do sistema de plantio direto. Rev Bras Eng Agric Ambient. 2007;11:489-96. https://doi.org/10.1590/S1415-43662007000500007

Pires LF, Borges JAR, Rosa JA, Cooper M, Heck RJ, Passoni S, Roque WL. Soil structure changes induced by tillage systems. Soil Till Res. 2017;165:66-79. https://doi.org/10.1016/j.still.2016.07.010

Reichert JM, Reinert DJ, Braida JA. Qualidade dos solos e sustentabilidade de sistemas agrícolas. Cienc Ambient. 2003;27:29-48.

Reichert JM, Rosa VT, Vogelmann ES, Rosa DP, Horn R, Reinert DJ, Sattler A, Denardin JE. Conceptual framework for capacity and intensity physical soil properties affected by short and long-term (14 years) continuous no-tillage and controlled traffic. Soil Tillage Res. 2016;158:123-36. https://doi.org/10.1016/j.still.2015.11.010

Rheinheimer DS, Fornari MR, Bastos MC, Fernandes G, Santanna MA, Calegari A, Canalli LBS, Caner $L$, Labanowski J, Tiecher T. Phosphorus distribution after three decades of different soil management and cover crops in subtropical region. Soil Till Res. 2019;192:33-41. https://doi.org/10.1016/j.still.2019.04.018

Rodale Institute. Crop rotations [internet]. Kutztown: Rodale Institute; 2021 [cited 2021 Jul 8]. Available from: https://rodaleinstitute.org/why-organic/organic-farming-practices/crop-rotations/.

Rollof G, Lutz RAT, Mello I. Índice de qualidade participativo do plantio direto. Foz Do Iguaçu: FEBRAPDP; 2011a. (Boletim técnico 02).

Rollof G, Lutz RAT, Mello I. Validação do índice de qualidade participativo do plantio direto. Ponta Grossa: FEBRAPDP; 2011b. (Boletim técnico).

Sá JCM, Cerri CC, Lal R, Dick WA, Piccolo MC, Feigl BE. Soil organic carbon and fertility interactions affected by a tillage chronosequence in a Brazilian Oxisol. Soil Till Res. 2009;104:56-64. https://doi.org/10.1016/j.still.2008.11.007

Sá JCM, Santos JB, Canalli LBS, Inagaki TM, Gonçalves DRP, Romaniw J, Ferreira AO, Briedis C. Manejo da matéria orgânica do solo (cobertura morta). In: Bertol OJ, Colozzi Filho A, Barbosa GMC, Santos JB, Guimarães MF, editors. Manual de manejo e conservação do solo e da água para o estado do Paraná. Curitiba: NEPAR-SBCS; 2019a. p. 114-9.

Sá JCM, Santos JB, Canalli LBS, Inagaki TM, Gonçalves DRP, Romaniw J, Ferreira AO, Briedis C. Sistema plantio direto. In: Bertol OJ, Colozzi Filho A, Barbosa GMC, Santos JB, Guimarães MF, editors. Manual de manejo e conservação do solo e da água para o estado do Paraná. Curitiba: NEPAR-SBCS; 2019b. p. 105-11.

Santin W. O Brasil possível - a biografia de Herbert Bartz. Londrina: Idealiza; 2018.

Santos HPR, Reis EM. Rotação de culturas em plantio direto. Passo Fundo: Embrapa Trigo; 2001.

Scheid A, Sírio L, Luiz W, Guimarães R, Carlos G, Silva A. Sistema plantio direto: Bases para o Manejo da Fertilidade do Solo. São Paulo: ANDA; 2018.

Scientific Electronic Library Online - SciELO. Pesquisa avançada [internet]. São Paulo: SciELO; 2021 [cited 2021 Jul 16]. Available from: https://search.scielo.org/.

Souza LS, Bertol I, Maria IC, Filho JFM, Lepsch IF, Filho AR. Terminologia básica utilizada em manejo e conservação do solo e água. In: Bertol I, Maria IC, Souza LS, editors. Manejo e conservação do solo e da água. Viçosa, MG: Sociedade Brasileira de Ciência do Solo; 2019. p. 1-17.

Telles TS, Dechen SCF, Guimarães MF. Institutional landmarks in Brazilian research on soil erosion: a historical overview. Rev Bras Cienc Solo. 2013;37:1431-40.

https://doi.org/10.1590/S0100-06832013000600001 
Telles TS, Lourenço MAP, Oliveira JF, Costa GV, Barboza GMC. Soil conservation practices in a watershed in Southern Brazil. An Acad Bras Cienc. 2019;91:e20180578. https://doi.org/10.1590/0001-3765201920180578

Telles TS, Righetto AJ, Lourenço MAP, Barbosa GMC. No-tillage system participatory quality index. Rev Bras Eng Agric Ambient. 2020;24:128-33. https://doi.org/10.1590/1807-1929/agriambi.v24n2p128-133

United Nations Organization. The sustainable development goals report 2016. New York: UN; 2016. Available from: https://unstats.un.org/sdgs/report/2016/the\%20sustainable\%20 development\%20goals\%20report\%202016.pdf.

Veloso MG, Angers DA, Chantigny MH, Bayer C. Carbon accumulation and aggregation are mediated by fungi in a subtropical soil under conservation agriculture. Geoderma. 2020;363:114159. https://doi.org/10.1016/j.geoderma.2019.114159

Waltrick PC, Machado MAM, Dieckow J, Oliveira D. Estimativa da erosividade de chuvas no estado do Paraná pelo método da pluviometria: Atualização com dados de 1986 a 2008. Rev Bras Cienc Solo. 2015;39:256-67. https://doi.org/10.1590/01000683rbcs20150147 